\title{
Öğretmen Adaylarının Duygu ve Kişilik Özellikleri ile Öğretim Yeterlikleri Arasındaki İlişkinin İncelenmesi*
}

\section{Fulya Köse ${ }^{1}$}

\author{
Gülay Bedir ${ }^{2}$
}

Type/Tür:

Research/Araştırma

Received/Geliş Tarihi:

February 10/10 Şubat 2020

Accepted/Kabul Tarihi:

October 23/ 23 Ekim 2020

Page numbers/Sayfa No:

1177-1203

Corresponding

Author/Illetişimden Sorumlu

Yazar:

fulyakose44@gmail.com

\section{$\checkmark$ iThenticate}

This paper was checked for plagiarism using iThenticate during the preview process and before publication. / $\mathrm{Bu}$ çalışma ön inceleme sürecinde ve yayımlanmadan önce iThenticate yazılımı ile taranmıştır.

\section{Copyright (c) 2020 by} Cumhuriyet University, Faculty of Education. All rights reserved.

\section{Öz}

$\mathrm{Bu}$ araştırmada öğretmen adaylarının duygu ve kişilik özellikleri ile öğretim yeterlikleri arasındaki ilişkinin ortaya çıkarılması amaçlanmıştır. İlişkisel tarama modelinde gerçekleştirilen araştırmanın evrenini 2017-2018 eğitim-öğretim yılında Kahramanmaraş Sütçü İmam Üniversitesi Eğitim Fakültesi'nde öğrenim gören lisans öğrencileri oluşturmaktadır. Araştırma evreninin tamamına ulaşıldığından ayrıca bir örneklem seçimine gidilmemiş̧ir. Araştırmada "Öğretmen Duyguları Ölçeği", "Temel Kişilik Özellikleri Ölçeği" ve "Öğretim Yeterliği Ölçeği" kullanılmıştır. Araştırma sonucunda, öğretmen adaylarının öğretmen duygularının en yüksek zevk boyutunda olduğu; ölçme aracının zevk boyutunda yaş değişkenine göre daha genç yaş grubundakilerin lehine, anne eğitim durumu değişkenine göre anne eğitim durumu düşük olanların lehine ve lise okul türü değişkenine göre daha az nitelikli okul türünde olanların lehine anlamlı bir farkın olduğu belirlenmiştir. Öğretmen adaylarının temel kişilik özelliklerinin en yüksek olduğu boyut "geçimlilik-uyumluluk" ve en düşük boyut ise olumsuz değerlik boyutudur. Araştırma sonucunda, öğretmen adaylarının öğretim yeterliklerinin en yüksek olduğu boyutun "sınıf yönetimi" boyutu, en düşük boyutunun ise "kişilerarası ilişki" boyutu olduğu belirlenmiştir. Öğretmen adaylarının öğretim yeterliliklerinin, duygu özelliklerinin "zevk" boyutu ile pozitif, "endişe ve kızgınlık" boyutları ile negatif yönlü anlamlı ilişkiler gösterdiği; kişilik özellikleri ile öğretim yeterlikleri arasında pozitif yönlü anlamlı ilişkiler bulunduğu, kişilik değişkeninin öğretmen adaylarının öğretim yeterliğindeki toplam varyansın yaklaşık \%12'sini açıkladığı belirlenmiştir. Araştırma bulgularına yönelik olarak öğretmen adaylarının eğitiminde öğretim yeterliklerini artırırken öğretmen adaylarının duygu ve kişilik özelliklerinin de dikkate alınması önerisinde bulunulmuştur.

Anahtar Kelimeler: Öğretmenlik, öğretmen adayları, duygu, kişilik, öğretim yeterliği

\section{Suggested APA Citation/Önerilen APA Atıf Biçimi: \\ Köse, F., \& Bedir, G. (2020). Öğretmen adaylarının duygu ve kişilik özellikleri ile öğretim yeterlikleri arasındaki ilişkinin incelenmesi. Cumhuriyet International Journal of Education, 9(4), 1177-1203. http://dx.doi.org/10.30703/cije.687467}

\footnotetext{
*Bu çalışma, birinci yazarın ikinci yazar danışmanlığında tamamladığı yüksek lisans tezinden üretilmiştir.

1 Öğretmen, MEB, Kahramanmaraş/Türkiye

Teacher, MEB, Kahramanmaraş/Turkey

e-mail: fulyakose44@gmail.com ORCID ID: orcid.org/0000-0003-4101-1630

2 Doç. Dr., Kahramanmaraş Sütçü İmam Üniversitesi, Eğitim Programları ve Öğretim, Kahramanmaraş/Türkiye Associate Professor, Kahramanmaraş Sütçü İmam University, Education Programs and Teaching, Kahramanmaraş/Turkey e-mail: gbedir@ksu.edu.tr ORCID ID: orcid.org/0000-0003-3488-6340
} 


\title{
An Analysis Of The Relationship Between Prospective Teachers' Emotion And Personality Traits With Their Teaching Efficacy
}

\begin{abstract}
This research aims to identify prospective teachers' emotional and personality traits along with their teaching efficacy. Having a relational survey model, the population of the research consisted of students studying at the Faculty of Education in Kahramanmaraş Sütçü İmam University during the 2017-2018 academic year. Since the entire research population was reached, no sample selection was made. This research employed three data collection tools as "Teacher Emotion Scale", "Basic Personality Traits Scale" and "Teaching Efficacy Scale". Research results have revealed that prospective teachers' teaching emotions are at the highest level in terms of the enjoyment dimension. A statistically significant difference has been identified across the dimension of enjoyment depending upon their age in favor of those with lower ages, mother educational status in favor of lower educational status and high school type in favor of less qualified high schools. The results of the research have also suggested that "Agreeableness-Conscientiousness" stand as the dimensions that prospective teachers have the highest personality traits, while the lowest dimension is the negative valence. Research findings revealed that prospective teachers had the highest level of teaching efficacy in "classroom management" dimension and the lowest in "interpersonal relationships". Besides, a positive relationship was identified between the "enjoyment" dimension of emotions and teaching efficacy; whereas, a negative relation was determined between the dimensions of "anger and anxiety" and teaching efficacy. Moreover, a positive and significant relations was found between personality traits and teaching efficacy. The personality variable was noted to explain approximately $12 \%$ of the total variance in terms of the prospective teachers' teaching efficacy. The research results provide recommendations based upon the idea that prospective teachers' emotion and personality traits should be taken into consideration while increasing their teaching efficacy.
\end{abstract}

Keywords: Teaching, prospective teachers, emotion, personality, teaching efficacy

\section{Giriş}

Eğitim, insanın erdemli, kâmil ve mükemmel bir canlı haline gelme ya da getirilme süreci olarak ifade edilebilir (Şişman, 2015: 3). İnsanın bu şekilde yetiştirilmesinde kuşkusuz en büyük etkenlerden biri öğretmenlerdir. Öğretmenlik mesleği bu nedenle üzerinde durulması ve en ince ayrıntılarıyla düşünülmesi gereken bir meslek olma özelliği taşımaktadır. Bu bakımdan öğretmenlerin kişiliklerinin öğretmenlik mesleğine uygunluğu, öğretmenlik mesleğine ilişkin duygu ve tutumları, yetiştirilme süreçleri ve öğretim yeterlikleri gibi etkenlerin üzerinde durulması gereken konular olduğu ifade edilebilir. Eğitimin genel olarak amacı, bireyi topluma faydalı hale getirebilmektir. Bu düşünceden hareketle bilim ve teknoloji dünyasındaki bütün modern gelişim ve değişimlerin gölgesinde öğrencinin sosyal bir birey haline gelmesi, okulda edindiklerini günlük yaşama aktarabilmesi kısacası topluma faydalı bir birey olabilmesi için öğretmenin bu konulardaki yeri ve yeterliği ihmal edilemeyecek bir unsur olarak ortaya çıkmaktadır (Öztürk, 2004: 7).

Bir ülkede hem gelecek kuşakların hem de ülkelerin ihtiyaç duyduğu insan gücünün yetişmesinden, eğitimin önemli unsuru olarak bilinen öğretmenin önemli yükümlülüğünün olduğu ifade edilebilir. Çocuk çevresinden kimi zaman eğitsel kimi zaman da eğitsel olmayan tecrübeler kazanmaktadır. Çevre ile çocuk arasındaki bu durum, hiçbir zaman sona ermemektedir. Okul ve öğretmenin vazifesi, çocuğun 
yetişmesini sağlarken çevreden kazandığı eğitimle ilgili olmayan yaşantıları da eğitimle ilgili açıya çevirmektir (Küçükahmet, 1999: 1). Öğretim hizmeti ise öğrencilere, öğrenme-öğretme sürecinde neleri, niçin ve nasıl yapacaklarını ifade etme; öğrencileri, öğrenmeleri beklenen davranışları denemeye; öğrencilerin sergiledikleri deneme davranışlardan istenenleri ya da gidişata göre ona yakın olanları pekiştirme; deneme davranışlardan istenene uzak olan ya da gidişattan çok uzak olanları onarma isimleri altında toplanabilecek önlemlerden oluştuğu ifade edilebilir (Özçelik, 2014: 5). Öğretmenlerin sahip olmaları gereken öğretim yeterliği, öğretimin belirleyicisi konumundadır. Öğretim ise bir dersin öğretim programında tespit edilen kurallara uyan bir öğrenme-öğretme süreci için gereken çalışmaların olması ve bu sürecin yerine getirilmesi ve bu sürecin ürün olarak meydana gelmesi için beklenen davranışların tamamı gözleninceye dek oldukça etkili ve verimli bir durumda devam ettirilmesi hizmetleri anlamına gelmektedir (Özçelik, 2014: 5). Öğretim, öğretmenler yoluyla olur. Öğretmenler, kendilerini öğrenciler ve dersler ile bağlayan kumaşı dokurken; kalp, ipliklerin bağlandığı bir dokuma görevini görür (Palmer, 2016: 61).

Duyguların insan yaşamında önemli bir yeri vardır. Çünkü duygular bireyler arası ilişkilere yön ve şekil verir. Enerjinin spesifik ve değerlendirici bir biçimde kullanılması duygular aracılığıyla olur (Tuğrul, 1999). Duygular, belli bir uyarıcı karşısında çoğunlukla içsel olarak ortaya çıkıp devinimsel tepkilere sebep olan inşa edilmiş hislerdir (Kervancı, 2008). Bu bakımdan duyguların insan yaşamında önemli bir yere sahip oldukları ve yaşamı boyunca insanı etkileyebildikleri ifade edilebilir.

Duyguların eğitim ortamlarında gerek öğrencilerin gerekse öğretmenlerin davranışlarına etki ettiği, onların davranışlarına yön verdiği ifade edilebilir. Bu yönüyle heyecan uyandıran iç yaşantılar olarak da tanımlanabilen duyguların, hedeflere yönelik davranışların itici güç kaynağı olduğu ve insanın kendini eğitirken ilk adımının da duygularını rahatça ifade etmesinden geçtiği belirtilebilir (Dökmen, 2000: 111).

Duygular kadar davranışlara yön veren başka bir güç kaynağ1 ise bireylerin kişilikleridir. Kişilik, kişiyi yapılaştıran ve onun toplumdaki rolünü koşullandıran bir örgütlenmedir (Yavuzer, 2001: 171). Atkinson, Atkinson ve Hilgard ise (1995) kişiliği, bir insanın etrafına uyumunu sağlayan karakteristik davranış şekilleri ve düşünme biçimleri olarak tanımlamışlardır. Bireyin fiziksel yapısını, yeteneklerini, güdülerini, gereksinimlerini, heyecansal tepkilerini ve geçmiş tecrübelerini içine alan kişilik, karmaşık ancak bireyin kendine has bütünü olup statik olmayan yani her an hareketli, değişmeye açık bir bütün olmasıyla beraber fazlaca devamlılı̆̆a da sahiptir (Tan, 2000). Bireyin kişiliğini onun kalıtsal potansiyeli ve yetenekleriyle çevresel etkenler ve öğrenme yaşantıları sonucu gelişen duygu, düşünce ve davranış biçimi oluşturur (Cirhinlioğlu, 2001).

Bireyin kişiliğinin şekillenmesinde aile, sosyal çevre ve genetik faktörler gibi birçok unsurun etkisinden bahsedilebilir. Kişiliğin oluşumunda küçük yaşlardan itibaren insan hayatına giren öğretmenlerin rolü ise yadsınamaz. Çünkü öğretmen davranışları yalnızca bireyin öğretim boyutu ile sınırlı kalmayıp onun duygu ve kişilik dünyasını da etkiler. Bireylerin hayatında önemli bir yeri olan öğretmen davranışlarının temelinde ise yine öğretmenlerin duyguları ve kişilikleri yatar. Bir birey olarak öğretmenin sahip olduğu bu duyguların ve kişiliğin özelde öğrencileri genelde ise toplumu etkilediği ifade edilebilir. Bireye ve topluma olan bu etkisinden 
dolayı öğretmenlerin lisans programlarına seçim ve sonrasındaki yetiştirilme süreçlerinde duygu ve kişilik özelliklerinin göz ardı edilmemesi gerekmektedir. Çünkü duygular ve kişilik özellikleri öğretmenlerin öğretim yeterliklerini doğrudan etkilemektedir (Ekin, 2018: 56).

Öğretmenlerin eğitim-öğretim süresindeki işlevlerinden biri de öğrencide öğrenme durumlarını gerçekleştirmektir. Öğrenme, davranışta kalıcı bir değişmenin olması iken öğretme, bireyin öğrenmesini sağlama eylemi, öğretim ise öğrenmeöğretme sürecini içerir. Öğretimin belirli ögeleri bulunmaktadır. Öğretimin ögeleri (1) öğrencilere, öğrenme-öğretme sürecinde neleri, niçin ve nasıl yapacaklarını bildirme, (2) öğrencileri etkileşimlere katılmaya özendirme, (3) öğrencilerin istendik davranışlarını pekiştirme ve (4) istendik olmayan davranışları düzeltme isimleri altında toplanmaktadır (Özçelik, 2014: 5). Öğretimin bu ögelerinin gerçekleştirilmesi ise öğretmenlerin öğretim yeterlikleri ile de doğrudan ilgilidir.

Öğretim yeterliği öğretmenlerin sahip olması gereken mesleki yeterlikler arasında yer almakta ve pek çok alt boyutu içerisinde barındırmaktadır. Ders tasarımı, kişilerarası ilişki, öğretim stratejisi, teknoloji kullanımı, sınıf yönetimi ve öğretimi değerlendirme bu alt boyutlar olarak sıralanabilir. Öğretmenin yetiştirilme sürecinde bu yeterlik alanlarını kazanması ve sonrasında kendini bu alanlarda sürekli olarak yenilemesi gerekmektedir. Öğretmenin alan bilgisi ve planlama yeterliği, sınıf yönetimi becerisi, öğretim yöntem-teknikleri, ölçme ve değerlendirme konularındaki sahip olması gereken yeterlikler öğretim yeterliğinin teorik ve pratikte birçok yeterlik alanını içerisinde barındırdığını göstermektedir. Bu bağlamda, öğretmen adaylarının duygu ve kişilik özelliklerinin incelenmesi; duygu ve kişiliğin öğretim yeterliği ile ilişkisinin belirlenmesi öğretmen yetiştirme sürecinde uygulayıcılara yol gösterebileceği ve araştırmanın bu yönüyle öğretmen yetiştirme sürecine katk1 sağlayabileceği düşünülmektedir. Bu bağlamda araştırmanın problem cümlesi; "Öğretmen adaylarının duygu ve kişilik özellikleri ile öğretim yeterlikleri arasında ilişki bulunmakta mıdır?" şeklinde belirlenmiştir. Buradan yola çıkarak bu araştırmanın amacı, öğretmen adaylarının duygu ve kişilik özellikleri ile öğretim yeterlikleri arasındaki ilişkinin incelenmesidir. Bu genel amaç doğrultusunda aşağıdaki sorulara cevap aranmıştır:

1. Öğretmen adaylarının öğretmen duyguları ne düzeydedir?

2. Öğretmen adaylarının temel kişilik özellikleri ne düzeydedir?

3. Öğretmen adaylarının öğretim yeterlikleri ne düzeydedir?

4. Öğretmen adaylarının öğretim yeterlikleri bazı demografik özellikler (cinsiyetlerine, yaşlarına, mezun oldukları lise türüne, öğrenim gördükleri bölüme, öğrenim gördükleri sınıfa göre) yönünden anlamlı olarak farklılaşmakta mıdır?

5. Öğretmen adaylarının duygu özelikleri ile öğretim yeterlikleri arasında anlamlı bir ilişki var mıdır?

6. Öğretmen adaylarının kişilik özelikleri ile öğretim yeterlikleri arasında anlamlı bir ilişki var mıdır?

7. Öğretmen adaylarının duygu ve kişilik özellikleri, öğretmen adaylarının öğretim yeterliklerinin anlamlı bir yordayıcısı mıdır? 


\section{Yöntem}

$\mathrm{Bu}$ araştırma, öğretmen adaylarının öğretim yeterliklerinin, duygu ve kişilik özelliklerinin kendi aralarında ilişkisi ve bu değişkenlerin bazı demografik değişkenler açısından farklılaşma durumlarını ortaya çıkarmak amacıyla yapılan ilişkisel bir çalışmadır. Tarama modelleri, geçmiş veya hali hazırda bir durumu bulunduğu şekliyle betimlemeyi amaçlayan araştırmalara uygun olan modeldir. İlişkisel tarama modelleriyse iki ve daha çok değişken arasındaki ilişkiyle birlikte değişimi de tespit etmeyi amaçlar (Karasar, 2005: 255). Bu bağlamda araştırmada, bağımlı değişken olan öğretmen adaylarının öğretim yeterlikleri ile bağımsız değişkenler olan duygu ve kişilik özellikleri arasındaki ilişki incelenmiştir.

\section{Çalışma Grubu}

Araştırmanın evreni, 2017-2018 eğitim öğretim yılında Kahramanmaraş Sütçü İmam Üniversitesi Eğitim Fakültesinde öğrenim gören lisans öğrencilerinden oluşmaktadır. Araştırma evreninin tamamına ulaşıldığından ayrıca bir örneklem seçimine gidilmemiştir. Uygulamanın yapıldığı günlerde derste bulunmayan öğrenciler ile ölçek maddelerinin önemli bir kısmını boş bırakan öğrenciler araştırmanın kapsamı dışında bırakılmıştır. Bu nedenle toplam 527 lisans öğrencisi araştırmanın örneklemini oluşturmaktadır. Değerlendirmeye alınan 527 öğrencinin demografik özelliklerine ilişkin frekans (f) ve yüzde (\%) dağılımları Tablo 1'de verilmiştir. 
Tablo 1.

Öğrencilerin Demografik Özelliklerine İlişkin Frekans ve Yüzde Değerleri

\begin{tabular}{|c|c|c|c|}
\hline $\begin{array}{l}\text { Demografik } \\
\text { Değişkenler }\end{array}$ & & Frekans (f) & Yüzde (\%) \\
\hline \multirow{2}{*}{ Cinsiyet } & Kadın & 437 & 82,9 \\
\hline & Erkek & 90 & 17,1 \\
\hline \multirow{4}{*}{ Yaş } & $18-22$ & 449 & 86,3 \\
\hline & $23-27$ & 64 & 12,2 \\
\hline & $28-32$ & 5 & 0,9 \\
\hline & 33 ve üstü & 3 & 0,6 \\
\hline \multirow{4}{*}{ Sinıf Seviyesi } & 1.sinif & 201 & 38,1 \\
\hline & 2.sinif & 116 & 22,0 \\
\hline & 4.sinif & 108 & 19,4 \\
\hline & 3.sinif & 102 & 20,5 \\
\hline \multirow{6}{*}{ Bölüm } & Fen bilgisi öğretmenliği & 187 & 29,6 \\
\hline & Sinıf öğretmenliği & 156 & 35,5 \\
\hline & Türkçe öğretmenliği & 89 & 8,2 \\
\hline & Rehberlik ve psikolojik danışmanlık & 43 & 5,1 \\
\hline & Sosyal bilgiler öğretmenliği & 27 & 16,9 \\
\hline & İlköğretim matematik öğretmenliği & 25 & 4,7 \\
\hline \multirow{5}{*}{ Lise okul türü } & Anadolu lisesi & 321 & 26,6 \\
\hline & Genel lise & 140 & 60,9 \\
\hline & Mesleki ve teknik lise & 39 & 1,9 \\
\hline & Diğer & 17 & 7,4 \\
\hline & Fen lisesi & 10 & 3,2 \\
\hline \multirow{5}{*}{ Anne eğitim durumu } & İlkokul & 293 & 17,5 \\
\hline & Hiç okula gitmedi & 91 & 55,6 \\
\hline & Ortaokul & 74 & 14,0 \\
\hline & Lise & 47 & 8,9 \\
\hline & Üniversite & 21 & 4,0 \\
\hline \multirow{5}{*}{ Baba eğitim durumu } & İlkokul & 207 & 39,4 \\
\hline & Ortaokul & 115 & 21,8 \\
\hline & Lise & 115 & 21,8 \\
\hline & Üniversite & 75 & 14,5 \\
\hline & Hiç okula gitmedi & 12 & 2,5 \\
\hline TOPLAM & & 527 & 100 \\
\hline
\end{tabular}

Tablo 1'de görüldüğgü gibi, örneklemin çoğunluğunun kadın, 18-22 yaş aralığında, 1.sınıfta öğrenim gören, Fen Bilgisi Öğretmenliği bölümünde, Anadolu lisesinden mezun olan, anne eğitim durumu ilkokul ve baba eğitim durumu ilkokul olan öğrencilerden oluşmaktadır.

\section{Veri Toplama Araçları}

Veri toplama araçlarının araştırmada kullanılabilmesi için araştırmacılardan gerekli izinler e-posta yoluyla; "Öğretim Yeterlik Ölçeği" için ise ölçeği Türkçeye uyarlayan Bedir'den (2015) gerekli izin şahsen alınmıştır. Ayrıca veri toplama araçlarının öğrencilere uygulanabilmesi için Kahramanmaraş Sütçü İmam Üniversitesi'nden resmi izin alınmıştır. Uygulamalar, öğrencilerin programda yer alan ders saatlerinin bitiminden sonra sınıflarında yapılmıştır. Uygulama esnasında öğrencilere cevapları içtenlikle vermelerinin önemi ve kişisel bilgilerin gizliliği ifade edilmiştir. Katılımın 
gönüllülük ilkesi çerçevesinde olduğu ifade edilmiş ve gönüllü olamayanlara ölçekler uygulanmamıştır. Uygulamanın içeriği konusunda gerekenler açıklanarak uygulamaya başlanmış ve sınıflardaki uygulamalar yaklaşık $40^{\prime}$ ar dakika civarında sürmüş̧ür.

Bu bölüm içerisinde araştırmanın veri toplama araçları ile ilgili bilgilere yer verilmiştir. Çalışmada "Öğretmen Duyguları Ölçeği", "Temel Kişilik Özellikleri Ölçeği" ve “Öğretim Yeterliği Ölçeği” veri toplama araçları olarak kullanılmıştır.

Öğretmen duyguları ölçeği. Öğretmen Duyguları Ölçeği (ÖDÖ), Frenzel, Pekrun, Goetz, Daniels, Durksen, Becker-Kurz ve Klassen (2016) tarafindan geliştirilmiş ve Alpaslan ve Ulubey (2017) tarafından Türkçeye uyarlanmıştır. Ölçekte kişilerin öğretmenlik mesleğine ilişkin duyguların belirtmede kullandıkları ifadeler yer almaktadır. ÖDÖ; zevk, endişe ve kızgınlık olmak üzere 3 alt boyuttan oluşmaktadır. Ölçek; " 1 = Kesinlikle katılmıyorum ve $4=$ kesinlikle katılıyorum" aralığında olmak üzere dörtlü likert şeklinde derecelendirilmiştir. Alpaslan ve Ulubey (2017), yapmış oldukları analizlerde Öğretmen Duyguları Ölçeğinin geneli için Cronbach Alpha değerini $\alpha=.82$, alt boyutlar içinse, $\alpha=.70$ ile $\alpha=.75$ arasında bulmuşlardır. Bu çalışmada ise ölçeğin geneli için Cronbach Alpha katsayısı bulunurken, zevk alt boyutu için $a=.79$, endişe alt boyutu için $a=.71$ ve kızgınlık alt boyutu için $a=.73$ olarak hesaplanmıştır. Veri toplama aracının yapı geçerliliğini test etmek için yapılan doğrulayıcı faktör analizi sonuçları Şekil 1'de gösterilmiştir.

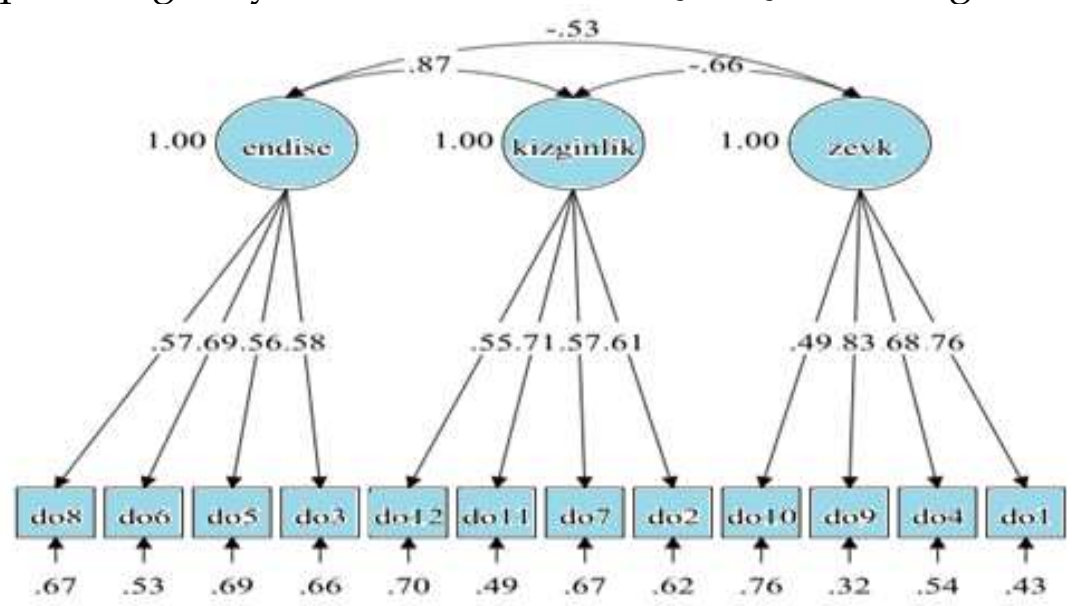

Şekil 1. Öğretmen duygu ölçeğinin doğrulayıcı faktör analizi

Şekil 1.'de yer alan diyagrama bakıldığında ölçeğin 3 faktörlü yapısının doğrulandığ 1 ve maddelerin faktör yük değerlerinin .49 ile .83 arasında değiştiği görülmektedir. Öğretmen Duygu Ölçeğinin doğrulayıcı faktör analizi sonucunda hesaplanan uyum indekslerinin $\left(\mathrm{x}^{2} / \mathrm{sd}=2,87 ; \mathrm{CFI}=0,94 ; \mathrm{RMSEA}=0,06\right)$ kabul edilebilir değerlere sahip olduğu görülmektedir.

Temel kişilik özellikleri ölçeği. Temel Kişilik Özellikleri Ölçeği (TKÖÖ), Gençöz ve Öncül (2012) tarafından Big- 5 teorisi temelinde geliştirilmiş ve tüm aşamaları Türk kültüründe tamamlanmış 45 maddeden oluşan bir ölçektir. TKÖÖ; "dışadönüklük, sorumluluk", "geçimlilik/ uyumluluk", "duygusal tutarsızlık", "gelişime açıklık", "olumsuz değerlik" olmak üzere altı alt boyuttan oluşmaktadır. Ölçek; " $1=$ Hiç uygun değil ve $5=$ çok uygun" aralığında olmak üzere beşli likert şeklinde derecelendirilmiştir. Gençöz ve Öncül (2012) tarafından yapılan çalışmada 
ölçeğin alt boyutlarının Cronbach Alpha değerleri $\alpha=.71$ ile $\alpha=.89$ arasında değişmektedir. Bu araştırmada ise ölçeğin boyutlarının Cronbach Alpha değerleri; dişadönüklük alt boyutu için $\alpha=.85$, sorumluluk alt boyutu için $\alpha=83$, geçimlilikuyumluluk alt boyutu için $\alpha=.79$, duygusal tutarsızlık alt boyutu için $\alpha=.76$, gelişime açıklık alt boyutu için $a=.74$, olumsuz değerlik alt boyutu için $a=.56$ olarak hesaplanmıştır.

Öğretim yeterlik ölçeği. Öğretim Yeterlik Ölçeği (ÖYÖ), Chang (2011) tarafından geliştirilmiş ve Bedir (2015) tarafından Türkçeye uyarlanmıştır. Dörtlü likert tipinde düzenlenen ölçek: ders tasarımı, öğretim stratejisi, teknoloji kullanımı, sınıf yönetimi, kişilerarası ilişkiler ve öğretimin değerlendirilmesi (Course Design, Instructional Strategy, Technology Usage, Classroom Management, Interpersonal Relation, Learning Assessment) boyutlarından oluşmakta ve 28 madde bulunmaktadır. Bedir (2015) tarafından yapılan çalışmada ölçeğin alt boyutlarının Cronbach Alpha değerleri; ders tasarımı alt boyutunda $\alpha=.70$, ögretim stratejisi alt boyutunda $\alpha=.76$, teknoloji kullanımı alt boyutunda $\alpha=.81$, sınıf yönetimi alt boyutunda $\alpha=.67$, kişilerarası ilişkiler alt boyutunda $\alpha=.73$, öğretimin değerlendirilmesi alt boyutunda $\alpha=.76$ olarak hesaplanmıştır. Bu araştırmada ise ölçeğin boyutlarının Cronbach Alpha değerleri; ders tasarımı alt boyutunda $\alpha=.79$, öğretim stratejisi alt boyutunda $\alpha=.79$, teknoloji kullanımı alt boyutunda $\alpha=.81$, sınıf yönetimi alt boyutunda $\alpha=.81$, kişilerarası ilişkiler alt boyutunda $\alpha=.74$, öğretimin değerlendirilmesi alt boyutunda $a=.83$ olarak hesaplanmıştır.

\section{Verilerin Analizi}

Araştırma sürecinde elde edilen veriler, SPSS 21 Paket Programı aracılığı ile analiz edilmiştir. Verilerin analizinde frekans dağılımları, ortalama değerler ve değişkenler arasındaki ilişkilerin anlamlılık durumu incelenmiştir. Öğretmen Duyguları Ölçeği, Temel Kişilik Özellikleri Ölçeği ve Öğretim Yeterlik Ölçeği Shapiro-Wilk Normallik Testi Sonuç değerleri Tablo 2'de verilmiştir.

Tablo 2.

Öğretmen Duyguları, Temel Kişilik Özellikleri Ölçeği ve Öğretim Yeterlik Ölçeği Shapiro-Wilk Normallik Testi Sonuçlan

\begin{tabular}{llll}
\hline Veri Toplama Araçları & İstatistik & Sd & $\mathbf{p}$ \\
\hline Öğretmen Duygu Ölçeği &, 963 & 527 & .00 \\
\hline Temel Kişilik Özellikleri Ölçeği &, 962 & 527 & .00 \\
\hline Öğretim Yeterlik Ölçeği &, 979 & 527 & .00 \\
\hline${ }^{*} \mathrm{p}<.05$ & & &
\end{tabular}

Tablo 2'de görüldüğü gibi Shapiro-Wilk normallik testi sonucunda katılımcıların tamamına ilişkin puanları normal dağılmadığ1 görülmektedir. Bu kapsamda, nicel verilerin analiz edilmesinde parametrik olmayan testler kullanılmıştır. Öğretmen adaylarının Öğretmen Duyguları, Temel Kişilik Özellikleri ve Öğretim Yeterlik Özellikleri puanlarının cinsiyet değişkenine göre farklılaşma durumunu tespit etmek amacı ile Mann-Whitney-U testi; yaş, bölüm, sınıf, lise okul türü, anne eğitim durumu ve baba eğitim durumu değişkenlerine göre farklılaşma 
durumunu tespit etmek amacı ile Kruskal Wallis-H testi kullanılmıştır. Ayrıca öğretmen adaylarının duygu, kişilik özellikleri ve öğretim yeterlikleri arasındaki ilişkinin incelenmesi için korelasyon analizi yapılmıştır. Korelasyon değerleri 0-0.30 aralığında düşük, 0.31-0.70 aralığında orta, 0.71-1 aralığında yüksek olarak kabul edilmiştir (Büyüköztürk, 2012:32).

\section{Bulgular}

Öğretmen Adaylarının Öğretmen Duygu Puanlarına İlişkin Bulgular

Öğretmen adaylarının öğretmen duygu puanlarına ilişkin istatistikler Tablo 3'de verilmiştir.

Tablo 3.

Öğretmen Adaylarının Öğretmen Duygu Puanlarına İlişkin İstatistikler

\begin{tabular}{lcc}
\hline Boyutlar & $\bar{x}$ & SD \\
\hline Zevk & 11,79 & 2,63 \\
\hline Endişe & 8,50 & 2,42 \\
\hline Kizgınlık & 8,41 & 2,57 \\
\hline
\end{tabular}

Tablo 3'de görüldüğü gibi, öğretmen adaylarının öğretmen duygularından en yüksek olanının zevk boyutu $(\bar{x}=11,79)$ olduğu görülmektedir. İkinci sırada endişe $(\bar{x}=8,50)$ boyutu yer almaktadır. Öğretmen adaylarının öğretmen duygularından en düşük olanının ise kızgınlık boyutunda $(\bar{x}=8,41)$ olduğu görülmektedir.

\section{Öğretmen Adaylarının Temel Kişilik Özelliklerine İlişkin Bulgular}

Öğretmen adaylarının temel kişilik özelliklerine ilişkin istatistikler Tablo 4'de gösterilmiştir.

Tablo 4.

Öğretmen Adaylarının Temel Kişilik Özelliklerine İlişkin İstatistikler

\begin{tabular}{lcc}
\hline Boyutlar & $\overline{\mathrm{x}}$ & $\mathrm{SD}$ \\
\hline Dişadönüklük & 20,11 & 3,34 \\
\hline Sorumluluk & 28,10 & 3,82 \\
\hline Geçimlilik-Uyumluluk & 34,62 & 4,02 \\
\hline Duygusal Tutarsılık & 25,10 & 6,36 \\
\hline Gelişime Açıklı & 21,58 & 4,39 \\
\hline Olumsuz Değerlik & 9,10 & 2,88 \\
\hline
\end{tabular}

Tablo 4'de görüldüğü gibi, öğretmen adaylarının temel kişilik özelliklerinden en yüksek düzeyde olanının geçimlilik-uyumluluk boyutu $(\bar{x}=34,62)$ olduğu görülmektedir. Öğretmen adaylarının temel kişilik özelliklerinin en düşük düzeyde olanının ise olumsuz değerlik boyutu $(\bar{x}=9,10)$ olduğu görülmektedir. 


\section{Öğretmen Adaylarının Öğretim Yeterliklerine İlişkin Bulgular}

Öğretmen adaylarının öğretim yeterlik düzeylerine ilişkin betimsel istatistikler Tablo 5 'de gösterilmektedir.

Tablo 5.

Öğretmen Adaylarının Öğretim Yeterliklerine İlişkin Betimsel İstatistikler

\begin{tabular}{lcc}
\hline Boyutlar & $\overline{\mathrm{x}}$ & $\mathrm{SD}$ \\
\hline Ders Tasarımı & 15,76 & 2,72 \\
\hline Öğretim Stratejisi & 16,53 & 2,77 \\
\hline Teknoloji Kullanımı & 15,88 & 2,90 \\
\hline Sınıf Yönetimi & 17,42 & 2,81 \\
\hline Kişilerarası İlişki & 10,32 & 1,75 \\
\hline Öğretimi Değerlendirme & 17,03 & 2,73 \\
\hline
\end{tabular}

Tablo 5'de görüldüğü üzere, öğretmen adaylarının öğretim yeterliklerinden en yüksek düzeyde olanının sinıf yönetimi boyutu $(\bar{x}=17,42)$ olduğu görülmektedir. Öğretmen adaylarının en düşük düzeyde ise kişilerarası ilişki boyutunda $(\bar{x}=10,32)$ öğretim yeterliklerine sahip oldukları görülmektedir.

\section{Öğretmen Adaylarının Öğretim Yeterliklerinin Cinsiyet Değişkenine İlişkin Bulgular}

Öğretmen adaylarının öğretim yeterlik düzeylerinin cinsiyet değişkenine göre analiz bulguları Tablo 6'da gösterilmektedir.

Tablo 6.

Öğretmen Adaylarının Öğretim Yeterliklerinin Cinsiyet Değişkenine Göre Mann-Whitney-U Testi Sonuçları

\begin{tabular}{|c|c|c|c|c|c|c|}
\hline Boyutlar & Cinsiyet & $\mathrm{N}$ & S.O & S.T. & $\mathrm{U}$ & $\mathrm{p}$ \\
\hline \multirow[t]{2}{*}{ Ders Tasarımı } & Kadin & 437 & 262,81 & 114848,00 & \multirow{2}{*}{19145,00} & \multirow{2}{*}{69} \\
\hline & Erkek & 90 & 269,78 & 24280,00 & & \\
\hline \multirow[t]{2}{*}{ Öğretim Stratejisi } & Kadın & 437 & 265,31 & 115939,50 & \multirow{2}{*}{19093,50} & \multirow{2}{*}{66} \\
\hline & Erkek & 90 & 257,65 & 23188,50 & & \\
\hline \multirow[t]{2}{*}{ Teknoloji Kullanımı } & Kadın & 437 & 259,76 & 113516,00 & \multirow{2}{*}{17813,00} & \multirow{2}{*}{ 15 } \\
\hline & Erkek & 90 & 284,58 & 25612,00 & & \\
\hline \multirow[t]{2}{*}{ Sınıf Yönetimi } & Kadın & 437 & 267,49 & 116894,50 & \multirow{2}{*}{18138,50} & \multirow{2}{*}{,24 } \\
\hline & Erkek & 90 & 247,04 & 22233,50 & & \\
\hline \multirow[t]{2}{*}{ Kişilerarası İlişki } & Kadın & 437 & 268,05 & 117136,00 & \multirow{2}{*}{17897,00} & \multirow{2}{*}{ 17 } \\
\hline & Erkek & 90 & 244,36 & 21992,00 & & \\
\hline \multirow[t]{2}{*}{ Öğretimi Değerlendirme } & Kadın & 437 & 267,43 & 116868,00 & \multirow{2}{*}{18165,00} & \multirow{2}{*}{ 25 } \\
\hline & Erkek & 90 & 247,33 & 22260,00 & & \\
\hline
\end{tabular}

${ }^{* \mathrm{p}<.05}$

Tablo 6'da görüldüğüu üzere, yapılan ilişkisiz ölçümler için 'Mann Whitney-U testi sonucunda anlamlı bir fark bulunmamaktadır ( $>$ >.05). Buna bağlı olarak öğretmen adaylarının öğretim yeterlik düzeylerinin cinsiyet değişkenine göre anlamlı düzeyde farklılaşmadığı ifade edilebilir. 
Öğretmen Adaylarının Öğretim Yeterliklerinin Yaş Değişkenine İlişkin Bulgular

Öğretmen adaylarının öğretim yeterliklerinin yaş değişkenine göre analiz bulguları Tablo 7'de gösterilmektedir.

Tablo 7.

Öğretmen Adaylarının Öğretim Yeterliklerinin Yaş Değişkenine Göre Kruskal Wallis-H Testi Sonuçlan

\begin{tabular}{|c|c|c|c|c|c|c|}
\hline Boyutlar & Yaş & $\mathrm{N}$ & S.O & $\mathrm{Sd}$ & $X^{-2}$ & $\mathrm{p}$ \\
\hline Ders Tasarımı & $\begin{array}{c}18-22 \\
23-27 \\
28-32 \\
33 \text { ve üstü }\end{array}$ & $\begin{array}{c}449 \\
64 \\
5 \\
3\end{array}$ & $\begin{array}{l}256,89 \\
285,95 \\
361,60 \\
176,67\end{array}$ & 3 & 5,37 & 14 \\
\hline Öğretim Stratejisi & $\begin{array}{c}18-22 \\
23-27 \\
28-32 \\
33 \text { ve üstü }\end{array}$ & $\begin{array}{c}449 \\
64 \\
5 \\
3\end{array}$ & $\begin{array}{l}257,12 \\
284,42 \\
314,20 \\
253,00\end{array}$ & 3 & 2,51 &, 47 \\
\hline Teknoloji Kullanımı & $\begin{array}{c}18-22 \\
23-27 \\
28-32 \\
33 \text { ve üstü }\end{array}$ & $\begin{array}{c}449 \\
64 \\
5 \\
3\end{array}$ & $\begin{array}{l}256,68 \\
283,18 \\
332,60 \\
315,33\end{array}$ & 3 & 3,33 & ,34 \\
\hline Sınıf Yönetimi & $\begin{array}{c}18-22 \\
23-27 \\
28-32 \\
33 \text { ve üstü }\end{array}$ & $\begin{array}{c}449 \\
64 \\
5 \\
3\end{array}$ & $\begin{array}{l}254,22 \\
298,87 \\
330,70 \\
351,67\end{array}$ & 3 & 7,25 &, 06 \\
\hline Kişilerarası İlişki & $\begin{array}{c}18-22 \\
23-27 \\
28-32 \\
33 \text { ve üstü }\end{array}$ & $\begin{array}{c}449 \\
64 \\
5 \\
3\end{array}$ & $\begin{array}{l}255,84 \\
287,18 \\
356,30 \\
315,83\end{array}$ & 3 & 5,07 & ,16 \\
\hline Öğretimi Değerlendirme & $\begin{array}{c}18-22 \\
23-27 \\
28-32 \\
33 \text { ve üstü }\end{array}$ & $\begin{array}{c}449 \\
64 \\
5 \\
3\end{array}$ & $\begin{array}{l}253,80 \\
304,43 \\
321,00 \\
312,17\end{array}$ & 3 & 7,60 &, $05^{*}$ \\
\hline
\end{tabular}

Tablo 7'de görüldüğü üzere, öğretmen adaylarının öğretim yeterlik seviyelerinin yaşa göre anlamlı biçimde farklılaşma durumunu tespit etmek üzere yapılan 'Kruskal Wallis- $\mathrm{H}^{\prime}$ testi neticesinde sadece öğretimi değerlendirme boyutunda istatiksel olarak anlamlı fark bulunmaktadır (öğretimi değerlendirme $x^{2}=7,60 ; p<.05$ ). Bu farklılığın kaynağını tespit etmek amacı ile 'Mann-Whitney-U' testi yapılmıştır.

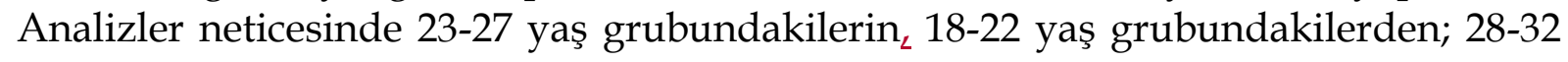


yaş grubundakilerin ise 23-27 yaş grubundakilerden daha yüksek düzeyde öğretimi değerlendirme yeterliklerine sahip oldukları görülmektedir.

Öğretmen Adaylarının Öğretim Yeterliklerinin Sınıf Değişkenine İlişkin Bulgular Öğretmen adaylarının öğretim yeterliklerinin sınıf değişkenine göre analiz bulguları Tablo 8'de gösterilmiştir.

Tablo 8.

Öğretmen Adaylarının Öğretim Yeterliklerinin Stnıf Değişkenine Göre Kruskal Wallis-H Testi Sonuçları

\begin{tabular}{|c|c|c|c|c|c|c|}
\hline Boyutlar & Sinif & $\mathrm{N}$ & S.O & Sd & $X^{-2}$ & $\mathrm{p}$ \\
\hline \multicolumn{7}{|l|}{ Ders Tasarımı } \\
\hline & 1.sinif & 201 & 244,07 & \multirow{4}{*}{3} & \multirow{4}{*}{27,71} & \\
\hline & 2.sinif & 116 & 236,04 & & & \multirow{3}{*}{$.00^{*}$} \\
\hline & 3.sinif & 102 & 266,03 & & & \\
\hline & $4 . \operatorname{sinif}$ & 108 & 329,20 & & & \\
\hline \multirow[t]{4}{*}{ Öğretim Stratejisi } & 1.sinif & 201 & 257,26 & \multirow{4}{*}{3} & \multirow{4}{*}{6,75} & \multirow{4}{*}{.08} \\
\hline & 2.sinif & 116 & 246,44 & & & \\
\hline & 3.sinif & 102 & 263,57 & & & \\
\hline & 4.sinif & 108 & 295,80 & & & \\
\hline \multirow[t]{4}{*}{ Teknoloji Kullanımı } & 1.sinif & 201 & 258,56 & \multirow{4}{*}{3} & \multirow{4}{*}{15,74} & \multirow{4}{*}{$.00^{*}$} \\
\hline & 2.sinif & 116 & 238,05 & & & \\
\hline & 3.sinif & 102 & 252,17 & & & \\
\hline & 4.sinif & 108 & 313,17 & & & \\
\hline \multirow[t]{4}{*}{ Sinıf Yönetimi } & 1.sinif & 201 & 250,88 & \multirow{4}{*}{3} & \multirow{4}{*}{17,00} & \multirow{4}{*}{$.00^{\prime}$} \\
\hline & 2.sinif & 116 & 238,06 & & & \\
\hline & 3.sinif & 102 & 266,04 & & & \\
\hline & 4.sinif & 108 & 314,35 & & & \\
\hline \multirow[t]{4}{*}{ Kişilerarası İliş̧ki } & 1.sinif & 201 & 256,35 & \multirow{4}{*}{3} & \multirow{4}{*}{6,57} & \multirow{4}{*}{.08} \\
\hline & 2.sinif & 116 & 250,94 & & & \\
\hline & 3.sinif & 102 & 259,70 & & & \\
\hline & 4.sinif & 108 & 296,33 & & & \\
\hline \multirow[t]{4}{*}{ Oğretimi Değerlendirme } & 1.sinif & 201 & 257,42 & \multirow{4}{*}{3} & \multirow{4}{*}{23,32} & \multirow{4}{*}{, $00^{*}$} \\
\hline & 2.sinif & 116 & 220,87 & & & \\
\hline & 3.sinif & 102 & 269,73 & & & \\
\hline & $4 . \operatorname{sinif}$ & 108 & 317,16 & & & \\
\hline
\end{tabular}

${ }^{*} \mathrm{p}<.05$

Tablo 8'de görüldüğü gibi, öğretmen adaylarının öğretim yeterliklerinin yaşa göre anlamlı biçimde farklılaşıp farklılaşmadı̆̆ını tespit etmek amacıyla yapılan 'Kruskal Wallis-H' testi neticesinde istatiksel olarak ders tasarımı, teknoloji kullanımı, sınıf yönetimi ve öğretimi değerlendirme boyutlarında anlamlı fark bulunmuş, öğretim stratejisi ve kişilerarası ilişki boyutunda ise anlamlı bir fark bulunmamıştır [(ders tasarımı $x^{2}=27,71 ; p<.05$, öğretim stratejisi $x^{2}=6,75 ; p>.05$, teknoloji kullanımı $x^{2}=15,74 ; p<.05$, sınıf yönetimi $x^{2}=17,00 ; p<.05$, kişilerarası ilişki $x^{2}=6,57 ; p>.05$, öğretimi değerlendirme $x^{2}=23,32 ; p<.05$, )] . Ders tasarımı, teknoloji kullanımı, sınıf yönetimi ve öğretimi değerlendirme boyutlarında olan farklılığın kaynağını tespit etmek amacı ile 'Mann-Whitney-U' testi yapılmıştır. Analizlerin sonucunda ders 
tasarımı boyutunda; 1.sınıfların 2.sınıflardan; 3.sinifların 2.sinıflardan; 4.sinıfların 3.sınıflardan daha yüksek seviyede öğretim yeterliklerine sahip oldukları görülmüştür. Teknoloji kullanımı boyutunda; 1.sınıfların 2.sınıflardan; 3.sınıfların 2.sınıflardan; 4.sınıfların 3.sınıflardan daha yüksek düzeyde öğretim yeterliklerine sahip oldukları görülmüştür. Sınıf yönetimi boyutunda; 1.sınıfların 2.sınıflardan; 3.sinıfların 2.sınıflardan; 4.sınıfların 3.sınıflardan daha yüksek düzeyde öğretim yeterliklerine sahip oldukları görülmüştür. Öğretimi değerlendirme boyutunda ise 1.sinıfların 2.sinıflardan; 3.sinifların 2.siniflardan; 4.sinifların 3.siniflardan daha yüksek düzeyde öğretim yeterliklerine sahip oldukları görülmüsstür.

\section{Öğretmen Adaylarının Öğretmen Duyguları ile Öğretim Yeterlikleri Arasındaki Illişkiye Yönelik Bulgular}

Öğretmen adaylarının öğretmen duygu puanları ile öğretim yeterlikleri arasındaki ilişkiye ilişkin sonuçlar Tablo 9'da gösterilmektedir.

Tablo 9.

Öğretmen Adaylarmm Duygu Özellikleri ile Öğretim Yeterlikleri Arasındaki İlişkiye Ait Spearman (Korelasyon) Analizi Sonuçları

\begin{tabular}{|c|c|c|c|c|c|c|c|c|}
\hline & 1 & 2 & 3 & 4 & 5 & 6 & 7 & 8 \\
\hline \multicolumn{9}{|l|}{ 1.Zevk } \\
\hline 2.Endişe & $-.403^{* *}$ & & & & & & & \\
\hline 3.K1zg1nlık & $-.461^{* *}$ & $.562 * *$ & & & & & & \\
\hline 4.Ders tasarımı & $.309^{* *}$ & $-.200^{* *}$ & $-.188^{* *}$ & & & & & \\
\hline $\begin{array}{l}\text { 5.Öğgretim } \\
\text { Stratejisi }\end{array}$ & $.250 * *$ & $-.172 * *$ & $-.156^{* *}$ & $-.596^{* *}$ & & & & \\
\hline $\begin{array}{l}\text { 6.Teknoloji } \\
\text { Kullanımı }\end{array}$ & $.141^{* *}$ & $-.198^{* *}$ & $-.132^{* *}$ & $.555^{\star *}$ & $.619^{* *}$ & & & \\
\hline 7.Sınıf Yönetimi & $.231^{* *}$ & $-.117^{* *}$ & $-.164^{* *}$ & $.477^{* *}$ & $.671^{* *}$ & $.551^{* *}$ & & \\
\hline $\begin{array}{l}\text { 8.Kişilerarası } \\
\text { İlişki }\end{array}$ & $.186^{* *}$ & $-.150 * *$ & $-.184^{* *}$ & $.426^{* *}$ & $.612^{* *}$ & $.522^{* *}$ & $\begin{array}{l}.651^{*} \\
*\end{array}$ & \\
\hline $\begin{array}{l}\text { 9.Öğretimi } \\
\text { Değerlendirme }\end{array}$ & $.221^{* *}$ & $-.183^{* *}$ & $-.136^{* *}$ & $.509^{* *}$ & $.665^{\star *}$ & $.587^{* *}$ & $\begin{array}{l}.658 * \\
*\end{array}$ & $.702^{* *}$ \\
\hline
\end{tabular}

$* * \mathrm{p}<.01$

Tablo 9 incelendiğinde, öğretmen adaylarının öğretmen duygu özelliklerinin alt boyutu olan zevk puanlarının öğretim yeterliliklerinin alt boyutu olan ders tasarımı $(\mathrm{r}=.31)$ ile pozitif ve orta düzeyde; öğretim stratejisi $(\mathrm{r}=.25)$, teknoloji kullanımı $(\mathrm{r}=.14)$, sınıf yönetimi $(r=.23)$, kişilerarası ilişkiler $(r=.19)$ ve öğretimi değerlendirme $(r=.22)$ alt boyutları ile de pozitif ve düşük düzeyde anlamlı ilişki gösterdiği görülmektedir.

Öğretmen adaylarının duygu özelliklerinin alt boyutu olan endişe puanlarının öğretim yeterliklerinin alt boyutu olan ders tasarımı $(\mathrm{r}=-.200)$, öğretim stratejisi $(\mathrm{r}=-$ .172), teknoloji kullanımı ( $\mathrm{r}=-.198)$, sınıf yönetimi ( $\mathrm{r}=-.117)$, kişilerarası ilişki ( $\mathrm{r}=-.150)$, öğretimi değerlendirme $(r=-.183)$ alt boyutları ile negatif yön ve düşük düzeyde anlamlı ilişki gösterdiği görülmektedir ( $p<.01)$.

Öğretmen adaylarının öğretmen duygu özelliklerinin alt boyutu olan kızgınlık puanlarının öğretim yeterliklerinin alt boyutu olan ders tasarımı ( $\mathrm{r}=-.188)$, öğretim stratejisi ( $\mathrm{r}=-.156)$, teknoloji kullanımı ( $\mathrm{r}=-.132)$, sınıf yönetimi ( $\mathrm{r}=-.164)$, kişilerarası 
ilişki ( $\mathrm{r}=-.184)$, öğretimi değerlendirme $(\mathrm{r}=-.136)$ alt boyutları arasında negatif yön ve düşük düzeyde anlamlı ilişki gösterdiği görülmektedir.

\section{Öğretmen Adaylarının Kişilik Özellikleri ile Öğretim Yeterlikleri Arasındaki İlişkiye Yönelik Bulgular}

Öğretmen adaylarının kişilik özellikleri ile öğretim yeterlikleri arasındaki ilişkiyi ilişkin değerler Tablo 10' da gösterilmiştir.

Tablo 10.

Öğretmen Adaylarının Kişilik Özellikleri ile Öğretim Yeterlikleri Arasındaki İlişkiye Ait Spearman (Korelasyon) Analizi Sonuçları

\begin{tabular}{|c|c|c|c|c|c|c|c|c|c|c|c|c|}
\hline & 1 & 2 & 3 & 4 & 5 & 6 & 7 & 8 & 9 & 10 & 11 & $\begin{array}{l}1 \\
2\end{array}$ \\
\hline \multicolumn{13}{|l|}{$\begin{array}{l}\text { 1.Dişa } \\
\text { dönüklük }\end{array}$} \\
\hline $\begin{array}{l}\text { 2.Sorumlu } \\
\text { luk }\end{array}$ &,- 037 & & & & & & & & & & & \\
\hline $\begin{array}{l}\text { 3.Geçimlili } \\
\text { k- } \\
\text { uyumlulu } \\
\text { k }\end{array}$ &,$- 149^{* *}$ &, $337^{* *}$ & & & & & & & & & & \\
\hline $\begin{array}{l}\text { 4.Duygusa } \\
1 \\
\text { Tutarsızlık }\end{array}$ &, $381^{* *}$ &,- 067 &,$- 143^{* *}$ & & & & & & & & & \\
\hline $\begin{array}{l}\text { 5.Gelişime } \\
\text { Açıklık }\end{array}$ &,$- 379^{* *}$ &, $336^{* *}$ &, $381^{* *}$ &,$- 207^{* *}$ & & & & & & & & \\
\hline $\begin{array}{l}\text { 6.Olumsuz } \\
\text { Değerlik }\end{array}$ &, $176^{* *}$ &,$- 217^{* *}$ &,$- 356^{* *}$ & $266^{* *}$ &,$- 160^{* *}$ & & & & & & & \\
\hline $\begin{array}{l}\text { 7.Ders } \\
\text { tasarımı }\end{array}$ &,$- 211^{* *}$ & $179^{* *}$ &, $299^{* *}$ &,$- 153^{* *}$ & $298^{* *}$ &,$- 168^{* *}$ & & & & & & \\
\hline $\begin{array}{l}\text { 8.Öğretim } \\
\text { Stratejisi }\end{array}$ &,$- 122^{* *}$ & $219^{* *}$ &, $331^{* *}$ &,- 061 &, $343^{* *}$ &,$- 177^{* *}$ &, $596^{* *}$ & & & & & \\
\hline $\begin{array}{l}\text { 9.Teknoloj } \\
\text { i } \\
\text { Kullanımı }\end{array}$ &,$- 163^{* *}$ & ,187** &, $286^{* *}$ &,$- 105^{*}$ & $324^{* *}$ & $-165^{* *}$ & ,555** & ,619** & & & & \\
\hline $\begin{array}{l}10 . \text { Sınıf } \\
\text { Yönetimi }\end{array}$ &,$- 096^{*}$ &, $174^{* *}$ &, $371^{* *}$ & -,075 & $249^{* *}$ &,$- 265^{* *}$ & $477^{* *}$ & ,671** &, $551^{* *}$ & & & \\
\hline $\begin{array}{l}\text { 11.Kişilera } \\
\text { rası İlişki }\end{array}$ &,$- 100^{*}$ &, $151^{* *}$ &, $302^{* *}$ &,$- 116^{* *}$ & ,197** &,$- 196^{* *}$ & $426^{* *}$ & ,612** &, $522^{* *}$ & $651^{* *}$ & & \\
\hline $\begin{array}{l}\text { 12.Öğreti } \\
\text { mi } \\
\text { Değerlend } \\
\text { irme }\end{array}$ &,$- 100^{*}$ & $197^{* *}$ &, $369^{* *}$ &,- 049 & $276^{* *}$ &,$- 223^{* *}$ &, $529^{* *}$ & ,665** &, $587^{* *}$ & $658^{* *}$ &, $702^{* *}$ & \\
\hline
\end{tabular}

$\begin{array}{rl}* * & p<.01 \\ * p & <.05\end{array}$

Tablo 10 incelendiğinde, öğretmen adaylarını kişilik özelliklerinin alt boyutu olan dişadönüklük puanlarının öğretim yeterliklerinin alt boyutları olan ders tasarımı $(\mathrm{r}=-, 211)$, öğretim stratejisi $(\mathrm{r}=-, 122)$, teknoloji kullanımı $(\mathrm{r}=-, 163)$, sınıf yönetimi $(\mathrm{r}=$ $-, 096)$, kişilerarası ilişki $(r=-, 100)$, öğretimi değerlendirme $(r=-, 100)$ alt boyutlarında negatif yön ve düşük düzeyde anlamlı ilişki gösterdiği görülmüştür $(\mathrm{p}<.01)$.

Öğretmen adaylarını kişilik özelliklerinin alt boyut olan sorumluluk puanlarının öğretim yeterliklerin alt boyutları olan ders tasarımı $(\mathrm{r}=, 179)$, öğretim stratejisi $(\mathrm{r}=$ ,219), teknoloji kullanımı ( $\mathrm{r}=$,187), sınıf yönetimi $(\mathrm{r}=$,174), kişilerarası ilişki $(\mathrm{r}=, 151)$, 
öğretimi değerlendirme $(\mathrm{r}=$,197) alt boyutlarında pozitif yön ve düşük düzeyde anlamlı ilişki gösterdiği görülmüştür $(\mathrm{p}<.01)$.

Öğretmen adaylarını kişilik özelliklerinin alt boyutu olan geçimlilik-uyumluluk puanlarının öğretim yeterliklerinin alt boyutları olan ders tasarımı $(r=, 299)$, teknoloji kullanımı $(\mathrm{r}=$,286), öğretimi değerlendirme $(\mathrm{r}=, 369)$ alt boyutlarında pozitif yön ve düşük düzeyde; öğretim stratejisi $(\mathrm{r}=, 331)$, sınıf yönetimi $(\mathrm{r}=, 371)$, kişilerarası ilişki $(\mathrm{r}=, 302)$ alt boyutlarında pozitif yön ve orta düzeyde anlamlı ilişki gösterdiği görülmüştür $(p<.01)$.

Öğretmen adaylarını kişilik özelliklerinin alt boyutu olan duygusal tutarsızlık puanlarının öğretim yeterliklerinin alt boyutları olan ders tasarımı $(\mathrm{r}=-, 153)$, teknoloji kullanımı (r=-,105), kişilerarası ilişki $(\mathrm{r}=-, 116)$ alt boyutlarında negatif yön ve düşük düzeyde anlamlı ilişki gösterdiği görülmüştür. Duygusal tutarsızlık ve öğretim stratejisi, sınıf yönetimi, öğretimi değerlendirme alt boyutlarıyla arasında ilişki bulunmamaktadir $(\mathrm{p}<.01)$.

Öğretmen adaylarını kişilik özelliklerinin alt boyutu olan gelişime açıklık puanlarının öğretim yeterliklerinin alt boyutları olan ders tasarımı $(\mathrm{r}=$,298), sınıf yönetimi $(r=, 249)$ kişilerarası ilişki $(r=, 197)$, öğretimi değerlendirme $(r=, 276)$ alt boyutlarında pozitif yön ve düşük düzeyde; öğretim stratejisi $(r=, 343)$, teknoloji kullanımı ( $\mathrm{r}=$,324) alt boyutlarında pozitif yön ve orta düzeyde anlamlı ilişki gösterdiği görülmüştür ( $\mathrm{p}<.01)$.

Öğretmen adaylarını kişilik özelliklerinin alt boyutu olan olumsuz değerlik puanlarının öğretim yeterliklerinin alt boyutları olan ders tasarımı ( $\mathrm{r}=-, 168)$, öğretim stratejisi $(\mathrm{r}=-$-177) teknoloji kullanımı $(\mathrm{r}=-, 165)$, sınıf yönetimi $(\mathrm{r}=-, 265)$, kişilerarası ilişki $(r=-, 196)$, öğretimi değerlendirme $(r=-, 223)$ alt boyutlarında negatif yön ve düşük düzeyde anlamlı ilişki gösterdiği görülmüştür $(\mathrm{p}<.01)$.

\section{Öğretmen Adaylarının Duygu ve Kişilik Özelliklerinin Öğretmen Adaylarının Öğretim Yeterliklerinin Yordayıcılığına İlişkin Bulgular}

Öğretmen adaylarının duygu ve kişilik özelliklerinin öğretim yeterliklerini yordamasına ilişkin değerler Tablo 11'de gösterilmiştir.

Tablo.11

Öğretim Yeterliğinin Yordanmasına İlişkin Çoklu Regresyon Analizi Sonuçları

\begin{tabular}{|c|c|c|c|c|c|c|c|c|}
\hline & Değişken & B & $\begin{array}{l}\text { Standart } \\
\text { Hata }\end{array}$ & B & $\mathrm{T}$ & $\mathrm{P}$ & $\begin{array}{l}\text { İkili } \\
\text { R }\end{array}$ & $\begin{array}{l}\text { Kismi } \\
\mathrm{r}\end{array}$ \\
\hline \multirow{4}{*}{ 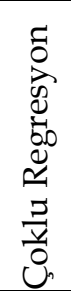 } & Sabit & 49.940 & 8.014 & - & 6.231 & .000 & - & - \\
\hline & Duygu & -0.262 & 0.160 & -0.075 & -1.636 & .103 & -.066 & -080 \\
\hline & Kişilik & 0.340 & 0.045 & 0.347 & 7.565 & .000 & .346 & .348 \\
\hline & $\begin{array}{l}R=0.354 \\
F=29.649\end{array}$ & $\mathrm{p}=$ & & & & & & \\
\hline
\end{tabular}

Tablo 11 incelendiğinde, çoklu regresyon analizi sonucunda kişiliğin öğretmen adaylarının öğretim yeterlikleri puanları ile orta düzeyde ve anlamlı olduğu görülmektedir $\left(\mathrm{R}=0.342, \mathrm{R}^{2}=0.117, \mathrm{p}<.01\right)$. Kişilik değişkeni, öğretmen adaylarının öğretim yeterliğindeki toplam varyansın yaklaşık \%12' sini açıklamaktadır. 
Regresyon sonuçlarına göre öğretim yeterliğinin yordanmasına ilişkin regresyon eşitliği (matematiksel model) aşağıda verilmiştir.

ÖĞRETİM YETERLİ̆̇̇̇=49.940+(0.340 KİŞİLIK) -(0.262DUYGU)

$\left(\mathrm{R}=0.354, \mathrm{R}^{2}=0.125, \mathrm{p}<.01\right)$.

\section{Tartışma, Sonuç ve Öneriler}

Araştırma sonucunda, öğretmen adaylarının öğretmen duygu özelliklerinin en yüksek düzeyde zevk boyutunda olduğu görülmektedir. İkinci sırada, endişe boyutunda ve en düşük düzeyde kızgınlık boyutunda olduğu görülmektedir. Çapraz ve Samancı (2014), yaptığ1 araştırmada öğretmen adaylarının bu mesleğin çocuk ve meslek sevgisi, sabır ve gayret gerektirdiğini ifade etmişlerdir. Güler'in (2017) yaptığı araştırmada da öğretmen ve öğrencilerin öğrenme ortamında yaşamış olduğu duyguların güven, mutluluk ve sevilme hissi gibi pozitif duygulardan oluştuğu ifade edilmiştir. Yurtseven'in (2020) yaptığı araştırmada ise öğretmen duygularının en yüksek umutsuzluk boyutunda olduğu görülmektedir. Araştırmanın bulguları, Çapraz ve Samanc1 (2014) ile Güler'in (2017) yaptığı çalışmalarla benzerlik gösterirken Yurtseven'in (2020) yaptığı çalışma ile farklılık göstermektedir. Öğretmen duygularının daha çok olumlu duygular içeren zevk boyutunda ortaya çıkması, öğretmen adaylarının öğretmenliğe karşı olumlu duygular beslediklerini ve öğretmenlik mesleğini sevdiklerinin bir sonucu olduğu belirtilebilir.

Öğretmen adaylarının temel kişilik özellikleri incelendiğinde, en yüksek düzeyde geçimlilik-uyumluluk boyutunda özelliklere sahip oldukları görülmektedir. En düşük düzeyde ise olumsuz değerlik boyutunda özelliklere sahip oldukları görülmektedir. Sevgi'nin (2017) yaptı̆̆ı araştırmada öğretmenlerin kişilik türleri; Yumuşak Başlılık, Dışa Dönüklük, Deneyime Açıklık, Sorumluluk, Duygusal Dengesizlik/Nevrotizm olarak belirlenmiştir. Kim ve MacCann'1n (2016) yaptı̆̆1 araştırmada öğrenciler kendileri, ideal öğretim üyesi ve ideal eğitmenleri için beş büyük kişilik özelliklerinden duygusal kararlılık ve vicdanlılık özelliklerini yüksek düzeyde belirtmişlerdir. Uysal'ın (2015) yaptığı araştırmada ise öğretmenlerin en az duygusal dengesizlik kişilik, en fazla ise açıklık kişilik niteliklerine sahip oldukları, orta düzeyde ise dışadönüklük, geçimlilik, sorumluluk kişilik özellikleri göstermekte olduklarını bulmuştur. Yılmaz Koca'nın (2009) yaptığı araştırmada, öğretmenlerin genelde endişeli kişilik niteliği gösterdikleri, en düşük kişilik niteliğinin ise bağımsızlık kişilik niteliği olduğunu belirlemiştir. Bulut ve Yıldız (2020), yaptıkları araştırmada ise üniversite öğrencilerinin sorumluluk boyutunda en yüksek ortalamaya sahip olduklarını bulmuşlardır. Araştırmanın sonucunda olumlu kişilik özelliklerinin en yüksek düzeyde olması, Sevgi (2017), Kim ve MacCann'in (2016) ve Bulut ve Yıldız'ın (2020) yaptığı araştırmanın sonuçlarıyla benzerlik göstermekte; Yılmaz Koca'nın (2009) yaptığı araştırmanın sonucu ile farklılık göstermektedir. Belirtilen araştırmalarda öğretmenler ve öğrencilerin olumlu kişilik özelliklerine sahip olduklarını ifade ettikleri görülmektedir. Ruhsal yönden sağlıklı bireylerin kişiliklerini olumlu olarak ifade etmeleri beklenir. Bu açıdan araştırmanın bu sonucu beklendik bir durum olarak ifade edilebilir.

Öğretmen adaylarının öğretim yeterlikleri ile ilgili olarak en yüksek düzeyde sınıf yönetimi boyutunda, en düşük düzeyde kişilerarası ilişki boyutunda olduğu görülmektedir. Bedir'in (2017) yaptığ1 araştırmada öğretim üyelerinin kendilerini en 
yeterli gördükleri boyut sınıf yönetimi boyutu, son sırada öğretimin değerlendirilmesi boyutu yer almıştır. Bedir'in (2015) yaptığı araştırmada ise öğretmenlerin kendilerini en yeterli gördükleri boyutun sınıf yönetimi olduğu, kendilerini en az yeterli gördükleri boyutun ise öğretim yöntemleri/stratejisi boyutu olduğu belirlenmiştir. Chang, Lin ve Song'un (2011) yaptığ1 araştırmada, öğretim üyelerinin öğretim yeterliklerinden en yüksekten düşüğge sıralandığında; ders tasarımı, sınıf yönetimi, kişilerarası ilişki, öğrenme değerlendirmesi, teknoloji kullanımı ve öğretim stratejisi olarak ortaya çıkmış; eğitim fakültesi üyeleri diğer fakültelerdeki öğretim üyelerinden daha yüksek bir yeterlik düzeyini göstermiş; kadınların sınıf yönetiminde ve öğrenme değerlendirmesinde erkeklerden daha yüksek puanlar aldığı görülmüş; altı yıldan az öğretim deneyimine sahip öğretim üyeleri, diğer öğretim üyelerine göre, öğretim yeterliklerinin ders tasarımı boyutunda düşük alg1 göstermişlerdir. Öğretim üyeleri ile eğitim deneyimi olmayanlar arasında anlamlı bir fark bulunmamaktadır. Araştırmanın sonucunda ortaya çıkan öğretmen adaylarının ders tasarımı boyutunda öğretim yeterliklerinin yüksek olması sonucu Bedir (2017), Bedir (2015), Chang, Lin ve Song'un (2011) yaptığı araştırma sonuçlarıyla benzerlik göstermektedir. Bu durum, öğretim yeterliklerinden en yeterli görülen boyutun sınıf yönetimi olabileceği şeklinde ifade edilebilir. Sınıfın iyi yönetilmesi, eğitim ve öğretimde başarılı olmak için ilk adım olarak kabul edilebilir (Demirel, 1999:190). Bu sebeple, öğretmenlerin kendilerini en iyi gördükleri öğretim yeterliği boyutunun sınıf yönetimi boyutu olduğu belirtilebilir. Öğretmen adaylarının cinsiyetleri öğretim yeterliklerini etkilememektedir. Bedir'in de (2017) yaptığ1 araştırmada öğretim üyelerinin cinsiyetlerine göre öğretim yeterliği açısından aralarında anlamlı bir fark bulunmamıştır. Coşkun, Gelen ve Öztürk'ün (2013) yaptığ1 araştırmada ise Türkçe öğretmeni adaylarının yeterliklere dönük algılarında cinsiyet açısından anlamlı bir farklılık bulunmadığı belirlenmiştir. Öztürk'ün (2004) yaptığı araştırmada öğretmen ve öğrenci görüşlerinde cinsiyet açsından fark bulunmamaktadır.

Menzi, Çalışkan ve Çetin'in (2012) yaptı̆̆ teknoloji kullanımı yeterliklerinin cinsiyet açısından, erkeklerin kadınlara göre bütün alt boyutlarda daha yeterli oldukları belirlenmiştir. Özgan, Yiğit, Aydın ve Küllük'ün (2011) yaptığı araştırmada, cinsiyet yönünden sınıf yönetiminde genelde fark görülmüştür. Şahin ve Altunay'ın (2011) yaptığı araştırmada sınıf yönetimi boyutunda cinsiyet yönünden fark görülmüştür. Cinsiyet yönünden uyarma davranışlarını erkeklerin kadınlara göre daha fazla sergiledikleri tespit edilmiştir. Bedir'in (2015) yaptığ1 araştırmada öğretmenlerin cinsiyete göre ölçeğin çeşitli boyutlarında öğretim yeterlik algılarında anlamlı bir fark olduğu belirlenmiştir.

Araştırma sonucunda cinsiyetin öğretim yeterliklerini etkilememesi Bedir (2017), Coşkun, Gelen ve Öztürk (2013), Öztürk'ün (2004) yaptığı araştırmanın sonuçlarıyla benzerlik gösterirken; Bedir (2015), Menzi, Çalışkan ve Çetin (2012), Özgan, Yiğit, Aydın ve Küllük (2011), Şahin ve Altunay'ın (2011) yaptığı araştırmanın sonuçlarıyla farklılık göstermektedir. Bu durum, Türk toplumunun ataerkil özellik göstermesi, erkeklerin otorite kabul edilmeleri, bu rolü üstlenen erkeklerin kendilerini kadınlardan daha iyi öğretim yeterliğine sahip olduklarını düşünmelerinden kaynaklandığ

Öğretmen adaylarının yaşları, öğretim yeterliklerini öğretimi değerlendirme boyutunda etkilemektedir. Öğretmen adaylarının yaşları yükseldikçe öğretim 
yeterlikleri de artmaktadır. Özgan, Yiğit, Aydın ve Küllük'ün (2011) yaptığ1 araştırmada yaş açısından genel olarak bir farklılık bulunmamıştır. Ancak daha ayrıntılı bir inceleme yapılarak becerilerin 16'sında $(\% 19,75)$ fark görülmüştür. Fark olan becerilerde genel olarak ifade edilirse 40 yaşın üzeri olanlarda gözlenmiştir. Araştırmanın bu sonucu Özgan, Yiğit, Aydın ve Küllük'ün (2011) yaptığı araştırmanın sonucu ile benzerlik göstermektedir. Bu durum, yaş ilerledikçe öğretmenliğe ilişkin tecrübenin ve öğretmenlik deneyimlerinin artması şeklinde açıklanabilir.

Öğretmen adaylarının duygu düzeylerinin zevk boyutunun, öğretim yeterliğinin bütün alt boyutlarıyla ilişkili olduğu görülmüştür. Öğretmen adaylarının zevk duygusu arttıkça öğretim yeterlikleri de artmaktadır. Endişe ve kızgınlık boyutu öğretim yeterliğinin bütün alt boyutlarıyla negatif yönde ilişkili bulunmaktadır. Öğretmen adaylarının endişe duygusu arttıkça öğretim yeterliklerinde düşme olduğu; öğretmen adaylarının kızgınlık duygusu arttıkça öğretim yeterliklerinde düşme olduğu görülmektedir. Duygu ile öğretim yeterliği arasında zevk boyutu ile pozitif yönde, endişe ve kızgınlık boyutu ile negatif yönde ilişki olduğu ifade edilebilir. Bu durumun öğretmen adaylarının öğretimi tasarlarken, sınıf ortamında öğrenciöğretmen etkileşiminde ve değerlendirme yaparken öğretmenlikten zevk aldıkları şeklinde açıklanabilir.

Öğretmen adaylarının kişilik özellikleri ile öğretim yeterlikleri arasında orta düzeyde anlamlı bir ilişki ortaya çıkmıştır. Öğretmen adaylarının dışadönüklüklerinin artması halinde öğretim yeterliklerinde düşme olduğu görülmektedir. Öğretmen adaylarının sorumluluk, geçimlilik-uyumluluk, gelişime açıklık özellikleri arttıkça öğretim yeterlikleri de artmaktadır. Öğretmen adaylarının duygusal tutarsızlık özelliklerinin artması halinde öğretim yeterliklerinin ders tasarımı, teknoloji kullanımı ve kişilerarası ilişki alt boyutlarında düşme olduğu görülmektedir. Yine öğretmen adaylarının olumsuz değerlik özelliklerinin artması halinde öğretim yeterliklerinde düşme olduğu görülmektedir. Roberts, Mowen, Edgar, Harlin ve Briers'in (2007) yaptığı araştırmada, öğretmen adaylarının kişilik tipleri ile öğretim yeterliği arasında ilişki bulunmuştur. Öğretim stratejileri yeterliği ve alg1 kişilik tipi arasında negatif yönlü bir ilişki; sınıf yönetimi yeterliği ve yargı kişilik tipi ile aralarında pozitif ilişki bulunmuştur. Araştırmanın bu bulgusu Roberts, Mowen, Edgar, Harlin ve Briers'in (2007) yaptığı araştırmanın sonucu ile benzerlik göstermektedir. Buscaglia (1987), kişiliğin yaşadığımız sürece hiç durmaksızın gelişip, ilerleyip değiştiğini ifade etmiştir. Kişilik, yaşam boyunda devam eden bir süreç olduğundan yaşamımızda yer alan bütün özelliklerimizi az ya da çok etkileyebileceği şeklinde düşünülebilir.

Araştırma sonunda, öğretmen adaylarının kişilik özellikleri ile öğretim yeterlikleri arasında bir ilişkinin olduğu ortaya çıkmıştır. Duygu özellikleri ile öğretim yeterlikleri arasında anlamlı bir ilişki bulunmamaktadır. Kişiliğin öğretmen adaylarının öğretim yeterliklerinin anlamlı bir yordayıcısı olduğu belirlenmiştir. Duygu ve heyecan, insan davranışlarının hayatta uyum ve olumsuzlukların önemli etmenleri arasındadır. Bunların ihtiyaçlar ve güdüler ile sıkı bir ilişkisi vardır. Duygular, düşünceler ve devimler psikolojik olayların birbirinden ayrılması çok güç olan temel öğelerdir. Duygu, düşünce ve davranış arasında doğrudan bir ilişki bir iç içe oluş vardır (Baymur, 1994: 77). Kişilik de duygular gibi hayatımıza yön verir. Bir anda oluşup bitmez, sürekli değişir, gelişir ve ilerler. Bu nedenledir ki öğretmenlik mesleğinin önemli bir yeterliği olan öğretim yeterliğinin duygu ve kişilikten 
etkilenmesi olasıdır. Bir öğretmenin kullandığı öğretim yöntemlerinden başlayıp, ders planlamasından, sınıf yönetiminden, sınıftaki etkileşimden, değerlendirmeye kadar birçok aşamada öğretmenin duyguları ve kişiliğinin öğretmenlik mesleğini başarılı bir şekilde yapmasında etkili olabileceği belirtilebilir.

Araştırma sonuçlarına dayalı olarak uygulayıcılara ve araştırmacılara dönük öneriler aşağıdadır:

\section{Uygulayıcılara Dönük Öneriler}

1. Araştırmada öğretmen adaylarının duygu düzeylerinin en yüksek zevk boyutunda olduğu ortaya çıkmıştır. Bu durum, öğretmenlik mesleği açısından istendik bir durumdur. Bunun daha da arttırılmasında dönük olarak öğretmen adaylarının 1.sınıflarında okul ortamıyla tanışmalarına daha çok imkân verecek etkinliklere daha fazla yer verilebilir.

2. Araştırmada öğretmen adaylarının temel kişilik özelliklerinden en yüksek düzeyde geçimlilik-uyumluluk boyutunda olduğu görülmektedir. Öğretmen adaylarının kişilik özelliklerinin diğer boyutlarının geliştirilmesi için ders programlarına kişilik gelişimini destekleyici dersler eklenebilir; öğretmen adaylarının dışadönük, sorumluluk sahibi ve gelişime, değişime açık olma durumlarını arttırıcı amaçlı sosyal faaliyetler düzenlenebilir.

3. Araştırmada öğretmen adaylarının öğretim yeterliklerinden en yüksek düzeyde sınıf yönetimi boyutunda, en düşük düzeyde kişilerarası ilişki boyutunda olduğu görülmektedir. Öğretmen adaylarının eğitim sürecinde yer alan derslere iletişim ve kişilerarası ilişki konularını içeren derslerin eklenerek yeterliklerinin bu yönünün geliştirilmesi sağlanabilir.

4. Araştırmada öğretmen duygu ve kişilik özellikleri arasında anlamlı bir ilişki olduğu ortaya çıkmıştır. Öğretmen adaylarından dişadönüklük özellikleri yüksek olanların öğretmenlikten duydukları endişe ve kızgınlık duygularının düşük düzeyde, zevk duygularının ise yüksek düzeyde olduğu görülmektedir. $\mathrm{Bu}$ durumda eğitim fakültelerine öğrenci seçiminde öğretmen adaylarının duygu ve kişilik testlerine tabi tutularak öğretmenliğe karşı olumlu duygulara ve kişilik yapısına sahip olup olmadıkları göz önünde bulundurabilir.

5. Araştırmada öğretmen adaylarının duygu ve kişilik özellikleri ile öğretim yeterlikleri arasında bir ilişki olduğu ortaya çıkmıştır. Öğretmen adaylarının öğretim yeterliğini artırırken öğretmen duygularının ve sahip oldukları kişilik özelliklerinin de dikkate alınması gerektiği ifade edilebilir. Eğitim fakültesinde yapılacak sosyal ve kültürel etkinliklerle farklı bölümlerin öğrencileri arasında etkileşim arttırılabilir. Aynı zamanda farklı bölümler arasında ortak seçmeli genel kültür dersleri arttırılarak hem birbirleriyle iletişimi hem de ögrretmenlik mesleğine ilişkin olumlu duyguları arttırılabilir.

\section{Araştırmacılara Dönük Öneriler}

1. Üniversite öğrencileri ile yapılan bu çalışmaya, 2017-2018 eğitim ve öğretim yılı bahar yarıyılında Kahramanmaraş Sütçü İmam Üniversitesi'nde Eğitim Fakültesi' nin farklı bölümlerinde okuyan öğrenciler katılmıştır. Yapılacak diğer araştırmalarda farklı fakültelerden ve farklı bölümlerden öğrenciler dahil edilebilir ve sonuçlar karşılaştırılabilir. 
2. Araştırmada örneklem olarak öğretmen adayları seçilmiştir. Yapılacak diğer çalışmalarda örneklem olarak öğretmenler veya akademisyenler seçilebilir.

3. Araştırmada veriler, nicel yöntem kullanılarak analiz edilmiştir. Yapılacak duygu, kişilik ve öğretim yeterliği arasındaki ilişki ile ilgili çalışmalarda veriler nitel araştırmalarla (gözlem, görüşme vb.) derinlemesine incelenebilir.

4. Araştırmada öğretmen adaylarının duygu ve kişilik özellikleri ile öğretim yeterliklerinin ölçülmesinde farklı ölçekler (olumlu-olumsuz duygu ölçeği, Hacettepe kişilik envanteri, Büyük beşli kişilik ölçeği, öğretmen kişilik özellikleri ölçeği, sıfatlara dayalı kişilik ölçeği, Minnesota çok yönlü kişilik envanteri, öğretmenlik anlayışı envanteri vb.) kullanılarak yapılabilir.

5. Araştırmada öğretmen adaylarının duygu, kişilik özellikleri ile öğretim yeterlikleri incelenmiştir. Başka bir araştırmada öğretim yeterlikleri üzerine etki edebileceği düşünülen tutum ve başarı faktörleri üzerinde de araştırma yapılabilir. Tutum ölçekleri (Öğretmenlik tutum ölçeği, Thurstone tutum ölçeği, Likert tutum ölçeği, Minnesota Öğretmen Tutum Ölçeği vb.), başarı testleri, ilgi testleri (Strong meslek ilgisi envanteri, Kuder ilgi envanteri, kendini değerlendirme envanteri vb.), yetenek testleri (sözel-sayısal ve soyut muhakeme testleri, Torrance yaratıcı düşünme testi vb.) duygu ve kişilik ölçekleri beraber kullanılarak araştırmalar genişletilebilir.

\section{Kaynakça}

Alpaslan, M. M., Ulubey, Ö. (2017). Öğretmen duygu ölçeğinin Türk kültürüne uyarlanmas1. International Periodical For The Languages, Literature And History Of Turkish Or Turkic, 12(25), 119-130.

Atkinson, L. R; Atkinson, C. R ve Hilgard, E. 1995. Psikolojiye giriş. Çev: K. Atakay, Atakay, A. Yavuz, Sosyal Yayınlar, İstanbul,926s.

Baymur, F. (1994). Genel psikoloji. İnk1lap Kitabevi: İstanbul, 319s.

Bedir, G. (2015). Perception of teaching efficacy by primary and secondary school teachers. International Electronic Journal of Elementary Education, 8(1),41-54.

Bedir, G. (2017). Perception of teaching efficacy by faculty members. International Journal on New Trends In Education and Their Implications, 8 (1),51-61.

Birimoğlu, B. (2015). Sını öğretmenlerinin kişilik özellikleri ile iş doyumları arasındaki ilişkinin incelenmesi: İstanbul İli Kadıköy ilçesi örneği. Yüksek lisans tezi. Yeditepe Üniversitesi, İstanbul.

Brigido, M; Mellado, L; Costillo, E and Mellado, V. (2014). Emotions İn Prospective Secondary Teachers When Teaching Science Content, Distinguishing by Gender. Research In Science and Technological Education, 32(2), 182-215. https:/ / doi.org/10.1080/02635143.2014.909800

Buscaglıa, L. (1987). Kişilik. Çev. N. Ebcioğlu, İnkılap Kitabevi: İstanbul, 160s.

Bulut, MB, Yıldız, M. Üniversite öğrencilerinin kişilik özelliklerinin yaşam doyumlarına etkisi. Türkiye Sosyal Araştırmalar Dergisi, 24 (2), 397-412.

Büyüköztürk, Ş. (2012). Sosyal bilimler için veri analizi el kitabı. Pegem A Yayıncılık: Ankara, 201s.

Chang, T.S., Lin, H.H. and Song, M. M. (2011). University faculty members' perceptions of their teaching efficacy. Journal Innovations in Education and Teaching International, 48 (1), 49-60. 
Cirhinlioğlu, F. G. 2001. Çocuk ruh sağlığı ve gelişimi. Nobel Yayınları, Ankara,248s.

Coşkun, E., Gelen, İ. ve Öztürk, E. (2013). Türkçe Öğretmeni adaylarının öğretimi planlama, uygulama ve değerlendirme yeterlilik algıları. Mustafa Kemal Üniversitesi Sosyal Bilimler Enstitüsü Dergisi, 6(12), 140-163.

Cüceloğlu, D. (1993). İnsan ve davranışı. Remzi Kitabevi: İstanbul,591s.

Çapraz, Ç. ve Samancı, O. (2014). Sınıf öğretmeni adaylarının öğretmenlik mesleğine yönelik görüşleri VE okul deneyiminin ilk gününde hissettikleri duygular. Atatürk Üniversitesi Sosyal Bilimler Enstitüsü Dergisi, 18 (1), 179-188.

Demirci, S. (2003). Öğretmenlerde beş faktör kişilik özellikleri ile iş doyumu arasındaki ilişkinin incelenmesi. Yüksek lisans tezi, Karadeniz Teknik Üniversitesi Sosyal Bilimler Enstitüsü, Trabzon.

Demirel, Ö. (1999). Planlamadan değerlendirmeye öğretme sanatı. Pegem A Yayıncılık: Ankara,294s.

Dökmen, Ü. (2000). Var olmak gelişmek uzlaşmak. Sistem Yayıncıllk: İstanbul, 402s.

Ekin, M. (2018). Sinı öğretmenlerin dersleri öğrenirken ve öğretirken hissettikleri duygular ile öğretim etkililik algıları arasındaki ilişkinin incelenmesi. Yüksek lisans tezi, Kahramanmaraş Sütçü İmam Üniversitesi Sosyal Bilimler Enstitüsü, Kahramanmaraş.

Gençöz, T. Ve Öncül, Ö. (2012). Examination of personality characteristics in a Turkish sample: development of basic personality traits inventory. The Journal of General Psychology, 139 (3), 194-216.

Gül, T.G. (2017). Üniversite öğrencilerinde bağlanma stilleri ile duygu dışavurum arasındaki ilişkinin incelenmesi. Yüksek lisans tezi, Haliç Üniversitesi Sosyal Bilimler Enstitüsü, İstanbul.

Güler, A. (2017). Öğretmen ve öğrencilerde ortaya çıkan duyguların öğretmen-öğrenci ilişkilerine etkileri. Yüksek lisans tezi, Gaziantep Üniversitesi Eğitim Bilimleri Enstitüsü, Gaziantep.

Karasar, N. (2005). Bilimsel araştırma yöntemleri, Nobel Akademik Yayıncılık: Ankara, $368 \mathrm{~s}$.

Kervanc1, F., 2008. Büro çalışanlarının duygu yönetimi yeterlik düzeylerinin geliştirilmesinde duygu yönetimi eğitimi programının etkisi, Yüksek lisans tezi, Gazi Üniversitesi Eğitim Bilimleri Enstitüsü, Ankara.

Kim, L. E. and Maccann, C. (2016). What is students' ideal university instructor personality? an investigation of absolute and relative personality preferences, Personality and Individual Differences, 12, 190-203.

Küçükahmet, L. (Ed.) (1999). Öğretmenlik mesleğine giriş. Alkım Yayınevi: İstanbul,225s.

Levent, B. (2011). Sını öğretmenlerinin kişilik özelliklerinin iletişim becerilerine etkisi. Yüksek lisans tezi, Selçuk Üniversitesi Eğitim Bilimleri Enstitüsü, Konya.

Menzi, N. Çalışkan, E. ve Çetin, O. (2012). Öğretmen adaylarının teknoloji yeterliliklerinin çeşitli değişkenler açısından incelenmesi. Anadolu Journal of Educational Sciences International, 2(1), 1-18.

Oktay, H. (2007). Illköğretim ve ortaöğretim kurumlarında çalışan öğretmenlerin motivasyonu ve kişilik özellikleri arasındaki ilişkinin incelenmesi. Yüksek lisans tezi, Yeditepe Üniversitesi, İstanbul.

Onur, B. (2000). Gelişim psikolojisi. İmge Kitabevi: Ankara,432s. 
Özçelik, D. A. (2014). Eğitim programları ve öğretim. Pegem Akademi: Ankara, 261s.

Özgan, H. Yiğit, C. Aydın, Z. ve Küllük, M.C. (2011). İlköğretim okulu öğretmenlerinin sınıf yönetimine ilişkin algılarının incelenmesi ve karşılaştırılması. Gaziantep Üniversitesi Sosyal Bilimler Dergisi, 10(1),617- 635.

Öztürk, Ç. (2004). Ortaöğretim coğrafya öğretmenlerinin öğretim yöntem ve teknikleri kullanabilme yeterlilikleri. Gazi Üniversitesi Kırşehir Ĕ̆itim Fakültesi, 5 (2), 75-83.

Palmer, P. (Ed.). (2016). Eğitim programlarında güncel sorunlar. Çev. N. T. Bümen, Pegem Akademi: Ankara, 370s.

Roberts, T. G. Mowen, D. L. Edgar, D. W. Harlin, J. F. and Briers, G. E. (2007). relationships between personality type and teaching efficacy of student teachers. Journal Of Agricultural Education, 48(2), 92-102. https:/ / doi.org/10.5032/jae.2007.02092

Sallığlu, G. (2002). Aleksitimik olan ve olmayan üniversite öğrencilerinin duygu ifade eden sözcük ve deyimlere yükledikleri duygu yoğunlukları. Yüksek lisans tezi, Hacettepe Üniversitesi Sosyal Bilimler Enstitüsü, Ankara.

Saygılı, G. (2010). Öğretmenlerin kişilik özellikleri ile okul iklimi algıları arasındaki ilişkinin incelenmesi. Yüksek Lisans Tezi, Yeditepe Üniversitesi Sosyal Bilimler Enstitüsü, İstanbul.

Sevgi, F. (2017). Sını öğretmenlerinin kişilik tipleri ile sınıf yönetim stilleri arasındaki ilişkinin farklı değişkenler açısından incelenmesi. Yüksek lisans tezi, Erciyes Üniversitesi Eğitim Bilimleri Enstitüsü, Kayseri.

Şahin, İ. ve Altunay, U. (2011). İlköğretim okulu öğretmenlerinin sınıf yönetimi davranışları. İlköğretim Online, 10(3), 905-918.

Şeker Sır, N. (2016). Öğretmen adaylarının 5 faktör kişilik kuramına göre kişilik özelliklerinin belirlenmesi ve bazı değişkenlere göre incelenmesi. Yüksek lisans tezi, Yıldız Teknik Üniversitesi Sosyal Bilimler Enstitüsü, İstanbul.

Şişman, M. (2015). Eğitim bilimine giriş. Pegem Akademi: Ankara,347s.

Tan, H. (2000). Psikolojik danışma ve rehberlik. MEB Yayınları, İstanbul, 342s

Tuğrul, Ç., 1999. Duygusal zekâ, Klinik Psikiyatri, 1, 12-20.

Uysal, Y. (2015). Öğretmenlerin kişilik özelliklerinin iş değerleri üzerine etkisi. Yüksek lisans tezi, Türk Hava Kurumu Üniversitesi Sosyal Bilimler Enstitüsü,

Uzun Özer, B. ve Tezer, E. (2008). Umut ve olumlu-olumsuz duygular arasindaki ilişki. Dokuz Eylül Üniversitesi Buca Eğitim Fakültesi Dergisi, 23, 81-86.

Yavuzer, H. (2001). Çocuk ve suç. Remzi Kitabevi: İstanbul,300s.

Y1lmaz Koca, S. (2009). Ortaöğretim okullarında görev yapan öğretmenlerin kişilik özellikleri ile örgütsel bağhlıkları arasındaki ilişkinin incelenmesi. Yüksek lisans tezi, Yeditepe Üniversitesi Sosyal Bilimler Enstitüsü, İstanbul.

Yurtseven, N. (2020). Teacher emotion questionnaire: a turkish adaptation, validity, and reliability study, Pegem Journal of Education and Instruction, 10(1), 251-282. https:// doi.org/10.14527/pegegog.2020.009 


\section{Summary}

\section{Introduction}

Education can be defined as the process of becoming a virtuous and perfect living person (Şişman, 2015: 3). Undoubtedly, teachers are the cornerstones in raising individuals in this way. Therefore, teaching has the distinction of being a profession that needs to be emphasized and considered with its finest details. In this respect, it is of great importance to emphasize the factors such as the appropriateness of the teachers' personalities to the teaching profession, their feelings and attitudes about the teaching profession, the upbringing processes and teaching efficacies (Öztürk, 2004: 7).

Teachers, who are regarded as significant elements of education, hold certain responsibilities for raising the manpower required by both future generations and countries in a country. Children may gain educational and non-educational experiences. This situation between the environment and the child never ceases. While educating children, the task of the school and the teacher is to adapt the noneducational experiences gained from the environment into an educational framework (Küçükahmet, 1999: 1).

Emotions have a significant place in human life as they shape relationships among individuals. Emotions can be said to affect both students' and teachers' behaviors in educational environments and manage their behaviors. Thus, emotions, which can also be defined as inner experiences that arouse excitement, are the driving forces of the behaviors towards the goals and that the first step of the human being is to express his emotions with ease while educating himself (Dökmen, 2000: 111).

Along with emotions, individuals' personalities are another source of power that directs behaviors. Personality is an organization that structures the individual and conditions his role in society (Yavuzer, 2001: 171). Family, social environment and genetic factors are paramount in shaping an individual's personality. In this context, the role of teachers cannot be underestimated as they care about human life from an early age during the formation of personality.

One of the roles of the teachers is to realize students' learning situations during the educational process. While learning is a permanent change in behavior, teaching involves the act of ensuring individual's learning and education involves the learningteaching process. Education holds certain elements which are (1) informing students what, why and how to do during the learning-teaching process, (2) encouraging students to participate in interactions, (3) reinforcing students' desired behaviors and (4) correcting undesired behaviors (Özçelik, 2014: 5). Performing these teaching elements is directly related to the teachers' teaching efficacies.

Teaching efficacy is among the professional competencies that teachers should have and includes many sub-dimensions such as course design, interpersonal relationship, teaching strategy, use of technology, classroom management and evaluation of teaching. Teachers need to acquire these efficacies and then to renew themselves continuously in these areas in the teacher training process. Hence, examining prospective teachers' emotions and personality traits in line with determining the relationship between emotion, personality and teaching efficacy are expected to open new gates for practitioners in teacher training process as well as contributing to teacher training process. In this regard, the problem statement of the research was identified 
as; "Is there a relationship between the prospective teachers' emotions and personality traits along with their teaching efficacy?"

\section{Method}

This research utilized a relational survey method with the aim of identifying whether there was the relationship between prospective teachers' teaching efficacy, emotion and personality traits and whether these variables differed across some demographic characteristics. The research attempts to determine the relationship between prospective teachers' teaching efficacy, which is a dependent variable, and their emotions and personality traits, which are independent variables. The research population consisted of undergraduate students studying at Kahramanmaraş Sütçü İmam University Faculty of Education during the 2017-2018 academic year. Since the entire research universe was reached, no sample selection was made and the entire sample was included in the research. Students who were not present in the course and those who left a significant portion of the scale items blank were not included in the research. Therefore, the research sample held 527 undergraduate students in total. "Teacher Emotion Scale", "Basic Personality Traits Scale" and "Teaching Efficacy Scale" were used as data collection tools.

\section{Discussion, Result and Findings}

Research findings revealed that prospective teachers' emotional characteristics were at the highest level in "enjoyment" dimension, which was followed by the dimension of "anxiety. Besides, prospective teachers were identified to have "anger" at the lowest level. In the study conducted by Çapraz and Samancı (2014), prospective teachers stated that teaching profession requires love of child and profession, patience and effort. Güler (2017) noted that the emotions experienced by teachers and students in the learning environment consisted of positive emotions such as trust, happiness and feeling of being loved.

Upon analyzing the prospective teachers' basic personality traits, they were found to have the highest level in terms of "compatibility-relevance" dimension, while the lowest level belonged to "negative valence". Sevgi (2017) identified the teachers' personality types as "Mildness, Extraversion, Openness to experience, Responsibility, Emotional Unbalance / Neuroticism". In their study, Kim and MacCann (2016) concluded that the students expressed "emotional stability and conscience" traits as a high level among the five great personality traits for themselves, their ideal instructor and ideal teachers. In the study conducted by Uysal (2015), the teachers were found to have the characteristic of "emotional imbalance" personality at the lowest level and the "openness personality at the highest level; moreover, they demonstrated "extraversion, compatibility, responsibility" personality traits at medium level.

Research findings suggested that prospective teachers considered themselves most efficient in the "classroom management" dimension and the least in "interpersonal relationship" dimension regarding the teaching efficacies. In the study carried out by Bedir (2017), the academicians considered themselves the most efficient in the "classroom management" dimension and the least efficient in the "evaluation of teaching" dimension. In another study conducted by Bedir (2015), the dimension that teachers regarded themselves the most efficient was determined as "class management, while the dimension that the participating teachers felt the least efficient 
was identified as "instructional methods/strategies". Chang, Lin and Song (2011) ranked the university instructors' teaching efficacies from the highest to the lowest as follows; course design, classroom management, interpersonal relationship, learning assessment, technology use and teaching strategy. Besides, education faculty instructors were found to have a higher level of efficacy than those in other faculties, and the female instructors were determined to have higher scores compared to males in classroom management and learning assessment dimensions. In addition, university instructors with less than six years of teaching experience had a low level of perception in the course design dimension compared to the others, and no significant difference was noted between university instructors and those without education experience. The result regarding the high level of teaching efficacy that prospective teachers had in the course design dimension is in line with those of Chang, Lin and Song (2011), Bedir (2015) and Bedir (2017). This paved the way for the fact that the most efficient dimension of teaching efficacies may be "classroom management". Good management of the classroom can be considered as the first step to be successful in education and teaching (Demirel, 1999: 190). Therefore, the teaching efficacy dimension that teachers regarded themselves most efficient can be the dimension of classroom management.

Research findings also showed that gender did not have an effect on the teaching efficacies. Similar findings emerged in the studies conducted by Bedir (2017), Coşkun, Gelen and Öztürk (2013), Öztürk (2004). On the contrary, it differed from the results of the studies conducted by Bedir (2015), Menzi, Çalışkan and Çetin (2012), Özgan, Yiğit, Aydın and Küllük (2011), Şahin and Altunay (2011). This may be due to the patriarchal character of the Turkish society, the acceptance of men as an authority, and the men's idea of having better teaching efficacy than women.

Prospective teachers' teaching efficacy was determined to vary across their ages in terms of "evaluation of teaching" dimension. Accordingly, the prospective teachers' teaching skills increase as their ages increase. In the study carried out by Özgan, Yiğit, Aydın, and Küllük (2011), no significant difference was identified across teachers' teaching efficacy in terms of age, yet a more detailed analysis was made and a significant difference was observed in 16 skills (19.75\%). This difference was found in those over 40 years old. This result is similar to that of Özgan, Yiğit, Aydın and Küllük's (2011) study. This may be explained by the increase in teaching experience as the age gets older.

As a result of the research, a relationship was determined between the "enjoyment" dimension of the prospective teachers' emotional levels and all subdimensions of teaching efficacy. As prospective teachers' sense of enjoyment increases, their teaching efficacy also increases. Besides, the "anxiety and anger" dimension was identified to be negatively related to all sub-dimensions of teaching efficacy. Namely, as the prospective teachers' anxiety and anger feelings increase, their teaching efficacies decrease. It can also be stated that there was a positive relation between emotion and teaching efficacy with the "enjoyment" dimension and a negative relationship with the "anxiety and anger" dimension. This may result from the fact that prospective teachers enjoy teaching while designing teaching environment, studentteacher interaction and assessment in the classroom environment. 
The findings revealed a significant and medium level relationship between prospective teachers' personality traits and their teaching efficacies. Accordingly, the prospective teachers' teaching efficacies decrease when their extraversion increases. As the prospective teachers' responsibility, compatibility-relevance, and openness to development characteristics increase, their teaching efficacy also increases. If their emotional inconsistency features increase, the teaching efficacies decrease in terms of course design, technology use and interpersonal relationship dimensions. Similarly, there occurred a decrease in the teaching efficacies as the prospective teachers' negative valence characteristics increase. In the study conducted by Roberts, Mowen, Edgar, Harlin and Briers (2007), a relationship was found between prospective teachers' personality types and their teaching efficacies. A negative relationship was identified between teaching strategies competence and perception personality type and a positive relationship was found between classroom management and judicial personality type. This finding is parallel to that of the study carried out by Roberts, Mowen, Edgar, Harlin and Briers (2007). Buscaglia (1987) stated that personality constantly develops, progresses and changes as long as we live. Since personality development is a continuing process throughout life, it may affect more or less all our features in our life.

In addition, a relationship was noted between prospective teachers' personality traits and their teaching efficacies; however, no significant relationship emerged between emotional characteristics and teaching efficacies. Personality was determined to be a significant predictor of prospective teachers' teaching efficacies. Emotion and excitement are among the significant factors of harmony and negativity of human behavior in life. They have a close relationship with needs and motives. Emotions, thoughts and movements are the main elements that are rather difficult to separate psychological events.

There is a direct relationship between emotion, thought and behavior (Baymur, 1994: 77). Personality directs our lives just like emotions. It does not occur immediately, it constantly changes, develops and advances. Thus, it is possible that teaching efficacy, which is an important part of teaching profession, is affected by emotion and personality. The emotions and personality of teachers in various dimensions such as teaching methods used by a teacher, lesson planning, classroom management, interaction in the classroom, evaluation may be effective in successfully performing the teaching profession.

\section{Araştırmanın Etik Taahhüt Metni}

Yapılan bu çalışmada "Yükseköğretim Kurumları Bilimsel Araştırma ve Yayın Etiği Yönergesi" kapsamında uyulması belirtilen tüm kurallara uyulmuştur. Yönergenin ikinci bölümü olan “Bilimsel Araştırma ve Yayın Etiğine Aykırı Eylemler” başlı̆̆ı altında belirtilen eylemlerden hiçbiri gerçekleştirilmemiştir.

Etik kurul izin bilgileri

Etik değerlendirmeyi yapan kurul adi $=$ Kahramanmaraş Sütçü İmam Üniversitesi Sosyal ve Beşerî Bilimler Etik Kurulu

Etik değerlendirme kararının tarihi $=03 / 05 / 2018$

Etik değerlendirme belgesi sayı numarası=81100045-044 


\section{Authors' Biodata/ Yazar Bilgileri}

Fulya KÖSE Kahramanmaraş Mimar Sinan İlkokulu'nda rehber öğretmen olarak görev yapmaktadir.

Fulya Köse is works as a counselor in Kahramanmaraş Mimar Sinan Primary School.

Gülay BEDİR Kahramanmaraş Sütçü İmam Üniversitesi'nde Eğitim Programları ve Öğretim Alanında Doçent olarak görev yapmaktadır.

Gülay Bedir is working as an Associate Professor in Education Programs and Teaching at Kahramanmaraş Sütçü Imam University. 